\title{
Development of Improved Fire Design Rules for Cold-formed Steel Wall Systems
}

\author{
Shanmuganathan Gunalan and Mahen Mahendran
}

\begin{abstract}
Traditionally the fire resistance rating of LSF wall systems is based on approximate prescriptive methods developed using limited fire tests. Therefore a detailed research study into the performance of load bearing LSF wall systems under standard fire conditions was undertaken to develop improved fire design rules. It used the extensive fire performance results of eight different LSF wall systems from a series of full scale fire tests and numerical studies for this purpose. The use of previous fire design rules developed for LSF walls subjected to non-uniform elevated temperature distributions based on AISI design manual and Eurocode3 Parts 1.2 and 1.3 was investigated first. New simplified fire design rules based on AS/NZS 4600, North American Specification and Eurocode 3 Part 1.3 were then proposed in this study with suitable allowances for the interaction effects of compression and bending actions. The importance of considering thermal bowing, magnified thermal bowing and neutral axis shift in the fire design was also investigated. A spread sheet based design tool was developed based on the new design rules to predict the failure load ratio versus time and temperature curves for varying LSF wall configurations. The accuracy of the proposed design rules was verified using the test and FEA results for different wall configurations, steel grades, thicknesses and load ratios. This paper presents the details and results of this study including the improved fire design rules for predicting the load capacity of LSF wall studs and the failure times of LSF walls under standard fire conditions.
\end{abstract}

Keywords: Fire design rules, Light gauge steel frame walls, Studs, Non-uniform temperatures, Standard fires, Thermal bowing, Neutral axis shift, Load ratio. 


\section{Introduction}

In recent times, light gauge steel framed (LSF) structures (Figure 1), such as cold-formed steel wall systems, are increasingly used in the Australian building industry, but without a full understanding of their fire performance. Cold-formed steel wall systems are made of thinwalled lipped channel section studs lined with gypsum plasterboards. These thin-walled steel studs are subjected to axial compression loads, and are protected by plasterboard linings during fire events as these linings not only delay the rapid temperature rise in steel studs but also provide lateral restraints to them. Since LSF walls are usually exposed to fire attack from one side, the studs are subjected to highly non-uniform elevated temperature distributions during fire events. Such non-uniform temperature distributions will induce complicated structural behaviour of studs involving thermal bowing and magnification effects, nonuniform distribution of strength and stiffness of steel across the cross-section and neutral axis shift (Figure 2). These effects due to non-uniform temperature distributions cause the thinwalled studs to be subjected to combined axial compression and bending actions during fire events. They compound the already complex structural behaviour of thin-walled steel studs involving local and global buckling effects as influenced by the levels of support provided by plasterboard linings during fires. Therefore it is important that suitable design rules that consider these effects are available to predict the axial compression strength of LSF wall studs and the failure times of LSF walls under standard fire conditions.

Traditionally the fire resistance rating (FRR) of load-bearing LSF wall systems is based on approximate prescriptive methods developed based on limited fire tests. Very often they are limited to standard wall configurations used by the industry. Hence suitable fire design rules were developed for LSF walls subjected to non-uniform temperature distributions by previous researchers [1-8]. Klippstein [1] and Gerlich et al. [2] developed them based on the AISI design manual while Eurocode 3 was used in [3-7]. However, these fire design rules were found to be either inaccurate at times or very complex and hence may not be used in routine fire design of LSF walls [9]. Therefore a detailed research study into the fire performance of LSF wall systems was undertaken to develop improved fire design rules using the results from a series of full scale fire tests and extensive numerical studies.

Ten full scale fire tests of load bearing LSF wall assemblies made of eight different wall configurations [10-12] including a new composite panel were first conducted under standard 
fire conditions (Table 1). Numerical studies were then undertaken using suitable LSF wall stud models $[11,13]$. The developed finite element models were validated by comparing their results with test results in [10-12]. The validated model was then used in a detailed numerical study into the axial compression strength of lipped channel studs used in both the conventional and the new composite panel systems to increase the understanding of their behaviour under non-uniform elevated temperature conditions and to develop fire design rules. The numerical study also included LSF walls made of other steel grades and thicknesses. Since the fire tests showed that the plasterboards provided sufficient lateral restraint until the failure of LSF wall panels, this assumption was also used in the analyses and was further validated by comparison with experimental results. Hence only the flexural buckling of studs about the major axis and local buckling were considered here.

This paper uses the extensive fire performance results of eight different LSF wall systems from fire tests and numerical studies to investigate the previous fire design rules developed in [1-8] for LSF walls subjected to non-uniform elevated temperatures, and proposes new fire design methods based on ambient temperature cold-formed steel design codes, AS/NZS 4600 [14], North American Specification [15] and Eurocode 3 Part 1.3 [16]. A spread sheet based design tool was developed based on the new design rules to predict the failure load ratio versus time and temperature curves for varying LSF wall configurations shown in Table 1.

This paper presents the details and results of this study aimed at developing improved fire design rules for predicting the load capacity of LSF wall studs and the failure times of LSF walls under standard fire conditions. It also includes brief details of the experimental and numerical studies of LSF walls conducted by the authors from which the results were used in this paper.

\section{Experimental Study}

Ten fire tests of LSF walls were conducted first to evaluate the fire performance of load bearing LSF wall assemblies. One wall specimen was tested to failure under an axial compression load at room temperature while ten wall specimens subjected to a constant axial compression load were exposed to standard fire conditions on one side (Table 1). Conventional LSF wall assemblies lined with single or double layers of plasterboard with or without cavity insulation were considered. A new LSF wall system based on a composite 
panel was proposed in which the insulation was placed externally between the two plasterboards [10-12]. The insulations used were glass, rockwool and cellulose fibres.

All the steel frames were built to a height of $2400 \mathrm{~mm}$ and a width of $2400 \mathrm{~mm}$ as shown in Figure 1. The studs and tracks used in the test frames were fabricated from G500 galvanized steel sheets with a nominal base metal thickness of $1.15 \mathrm{~mm}$. The measured yield strength and elastic modulus of steel were $569 \mathrm{MPa}$ and $213520 \mathrm{MPa}$, respectively, at ambient temperature. Test frames were lined on both sides by single or double layers of $16 \mathrm{~mm}$ gypsum plasterboards. Table 1 shows the details of wall specimens with eight different wall configurations used in this research.

The furnace was designed to deliver heat based on the standard fire curve as given in [17]. The loading frame was specially designed to load the individual studs of LSF wall specimens in compression from the bottom side using jacks (Figure 3(a)). The axial shortenings of the studs and the out-of-plane movements of the wall specimen were measured using LVDTS while $\mathrm{K}$ type thermocouples were used to measure the temperature development across the wall specimens during the fire tests.

In each fire test an axial compression load of $15 \mathrm{kN}$ (for a load ratio of about 0.2 ) or $30 \mathrm{kN}$ (for a load ratio of about 0.4) was applied to each stud, ie. 0.2 or 0.4 times the ultimate capacity of $79 \mathrm{kN}$ of each stud at ambient temperature as obtained from test. The load was held constant at room temperature before the furnace was started and then maintained throughout the fire test. During the fire test, the furnace temperature was regulated to follow the standard temperature-time curve. The test was stopped immediately after one or more of the wall studs failed, and the time to failure (FRR) was recorded. Figure 3(b) shows the LSF wall panel and the studs after failure while Table 1 shows their failure times. Further details about the experimental study and test results are given in [10-12].

\section{Finite Element Analyses}

A finite element model of LSF wall studs was developed with appropriate thermal and structural boundary conditions to simulate their behaviour under fire conditions and to determine the FRR. Finite element analyses were conducted under steady state conditions. Here, the non-uniform temperature distributions in the steel cross-section were raised to the 
measured temperatures of hot and cold flanges and web elements at a given time during the standard fire test and then maintained. A load was then applied in increments until failure. The stud failure load thus obtained was then expressed as a ratio of the ambient temperature stud capacity (load ratio) and plotted against time for each test. The use of steady state analyses thus provided load ratio versus time curves that can be used to find FRR and in the comparisons with fire design calculations.

S4R shell element type with a $4 \mathrm{~mm} \times 4 \mathrm{~mm}$ mesh size was selected based on detailed convergence studies. The measured mechanical properties were used to enable the comparison of FEA and test results. Poisson's ratio of steel was assumed as 0.3. The yield strength and elastic modulus reduction factors at elevated temperatures and the stress-strain curves were based on the predictive equations developed in [18]. The coefficient of thermal expansion $\alpha$ given in [19] was used.

Based on other numerical studies [5,7,20] and the experimental behaviour of studs [10-12], one of the two central studs with the vertical plasterboard joint against it (critical stud) was considered in the analyses. Pinned support conditions were simulated using rigid plates while the axial compressive load was applied at the section centroid at one end as shown in Figure 4. It was assumed that the plasterboard on both flanges provided sufficient lateral restraint until failure $[5,7,20]$.

The measured time-temperature profiles obtained from the fire tests were used as was done in [5,7]. The temperatures of the studs were measured at mid-height and quarter points throughout the fire tests [10-12]. Therefore the average measured temperatures were used over the entire stud length. Non-uniform temperature distribution across the stud (Figure 2) was considered in the finite element modelling of studs. The flange and lip temperatures were assumed to be the same with the web having a linear temperature distribution.

The local web buckling near the support was predominant in the first eigen mode of the elastic buckling analyses and also in the test results [10,12]. Therefore this eigen mode was used to introduce the initial geometric imperfection with an amplitude of $0.006 \mathrm{~b}$. The effect of residual stress on the ultimate capacity of LSF stud was found to be small at ambient 
temperature. It will be even more insignificant at elevated temperatures. Hence residual stresses were not considered for studs under fire conditions $[5,7,20]$.

The results from finite strip analyses (CUFSM) and tests [10,12] were used to validate the results of finite element analyses (FEA) at ambient temperature. Elastic buckling loads from CUFSM and FEA are $39.5 \mathrm{kN}$ and $39.8 \mathrm{kN}$, respectively. The ultimate failure loads from the test and FEA also agreed well (79.0 kN and $77.3 \mathrm{kN})$. The studs failed due to local buckling of web and flanges in the test $[10,12]$, which was confirmed by FEA.

Under fire conditions, many steady state analyses conducted in close time intervals led to a load ratio versus time curve for the LSF wall systems in Table 1. Figure 5(a) shows this curve for the case of LSF wall with glass fibre external insulation while Figure 5(b) shows the variation of load ratio with respect to the hot flange temperature at failure. As shown in these figures, the failure time and the critical hot flange temperature for Test 1 with a load ratio of 0.2 were obtained as 115 minutes and $600^{\circ} \mathrm{C}$. The main advantage of steady state FEA is that the figures such as Figure 5 can now be used to obtain the fire resistance rating (failure time) for any given load ratio. Table 1 gives the failure times predicted by steady state FEA for all the tests. These comparisons show that the developed finite element model accurately predicts the ultimate capacities and failure modes of studs subjected to axial compression under fire conditions. The developed finite element models were able to predict the failure times within 5 minutes. The validated model was used to extend the analyses of LSF wall systems made of other steel grades and thicknesses. In this case idealised time-temperature profiles developed based on the measured temperature values of the studs were used [11]. These results were also used to validate the fire design rules developed in this study based on [14-16]. Further details of numerical studies can be found in [11,13].

\section{Proposed Fire Design Rules based on Eurocode 3}

Design rules to find the ultimate capacity of LSF wall studs during standard fires were developed in [3-7] using Eurocode 3 Parts 1.2 [19] (fire code) and 1.3 [16] (ambient temperature code). A detailed review of the design rules proposed by [3-7] in relation to the applicability to LSF wall studs is given in [9,11]. Among them, Feng and Wang's [6] proposals based on Eurocode 3 Part 1.3 [16] design rules for ambient temperature conditions 
agreed well with the FEA and fire test results from this study. Therefore this study is also based on Eurocode 3 Part 1.3 to develop simplified fire design rules.

Among the previous studies except Feng and Wang [6], the minor axis bending was not considered. This is due to the availability of plasterboard restraint. Feng and Wang [6] included the neutral axis shift about the minor axis and corresponding bending moment. However, they showed that this effect is negligible and can be ignored in the fire design of LSF wall studs. Therefore the relevant equation in [16] for the combined actions of bending and axial compression can be reduced to

$\frac{N_{E d}}{\chi_{x} f_{y} A_{\text {eff }} / \gamma_{M 1}}+\frac{k_{x x}\left(M_{x, E d}+\Delta M_{x, E d}\right)}{\chi_{L T} f_{y} W_{e f f, x} / \gamma_{M 1}}=1$

where $N_{E d}$ is the applied axial compression load and $f_{y}$ is the basic yield strength; $A_{\text {eff }}$ is the effective cross-sectional area for axial compression; $\gamma_{M 1}$ is the partial factor for resistance of members to instability; $M_{X, E d}$ is the applied bending moment about the major axis; $\Delta M_{X, E d}$ is the additional moment; $W_{\text {eff, } x}$ is the effective section modulus for the maximum compressive stress in an effective cross-section that is subject to bending about the major axis; $\chi_{x}$ and $\chi_{L T}$ are the reduction factors due to flexural buckling and lateral torsional buckling; $k_{x x}$ is the interaction factor.

The bending moment about the major axis is caused by three effects due to the non-uniform temperature distribution in LSF wall studs. They are the pure thermal bowing due to temperature gradient, the neutral axis shift due to the deterioration of stiffness at non-uniform elevated temperatures and the magnification effects due to P- $\Delta$ effects. If the effective eccentricity of the combined effects is denoted as " $e$ ", the bending moment about the major axis is $N_{E d} e$. For members not susceptible to torsional deformations such as LSF wall studs, $\chi_{L T}$ is equal to 1.0. In addition to this, with the assumption of $\gamma_{M 1}$ equal to 1 , Equation 1 can be reduced to

$$
\frac{N_{E d}}{\chi_{x} f_{y} A_{e f f}}+\frac{k_{x x} N_{E d} e}{f_{y} W_{e f f, x}}=1
$$


In Equation 2, the component $f_{y} A_{\text {eff }}$ is the ultimate failure load for local buckling $N_{\text {eff }}$ and the component $f_{y} W_{\text {eff }, x}$ is the section moment capacity $M_{x, \text { eff }}$ of LSF wall stud. Hence the common equation used by all the previous researches [3-7] is

$$
\frac{N_{E d}}{\chi_{x} N_{\text {eff }}}+\frac{k_{x x} N_{E d} e}{M_{x, \text { eff }}}=1
$$

In order to find the ultimate load $N_{E d}$ of LSF wall studs under standard fire conditions, the parameters $k_{x x}, e, \chi_{x}, N_{\text {eff }}$ and $M_{x, \text { eff }}$ should be determined accurately by taking into account the effects of non-uniform elevated temperature distribution in LSF wall studs. The calculation methods of these parameters and associated assumptions varied in the previous studies and hence different ultimate loads were obtained for LSF wall studs.

The major differences among these previous studies are the effective areas used and the calculation of section moment capacities. Therefore in this study it is important to decide between the effective areas at ambient and elevated temperatures by investigating the section capacities of LSF wall studs under fire conditions.

\subsection{Section Compression Capacities of LSF Wall Studs under Fire Conditions}

The section compression capacity ( $N_{\text {eff }}$ ) of LSF wall stud under fire conditions is very hard to determine using experimental tests. The reason for this is its non-uniform temperature distribution and the resulting bending moment in addition to the applied compression load. Hence it is impossible to test a stud in pure compression with non-uniform temperature distributions to determine the section compression capacity. Therefore it was decided to use steady state finite element analyses of short LSF wall studs using ABAQUS. The half-wave length of local buckling waves was $70 \mathrm{~mm}$ according to the elastic buckling analyses of CUFSM. Hence a stud height of $210 \mathrm{~mm}$ was modelled to simulate three half waves. The thermal bowing and its magnification effects were eliminated in the model by using an extremely low thermal expansion co-efficient $\left(1 \times 10^{-20} /{ }^{\circ} \mathrm{C}\right)$. The neutral axis shift and corresponding bending moment were eliminated by applying the load at a pre-determined centroid on the new neutral axis calculated based on gross sectional dimensions and reduced elastic modulus. In the first step of FEA the non-uniform temperature distribution was applied while in the second step the load was applied to the new centroid calculated based on the 
applied temperatures. Figure 6 shows the failure mode of short LSF wall stud under fire conditions. A local buckling mode was obtained as expected.

The local buckling capacity according to Eurocode 3 Part 1.3 [16] was calculated by multiplying the effective area and the yield stress at elevated temperatures. Three possible yield stresses were investigated: yield stress at the average stud (web) temperature $\left(f_{\text {yweb }}\right)$, area based weighted average yield stress of the gross section $\left(f_{y b a r}\right)$ and yield stress at hot flange temperature $\left(f_{y h f}\right)$. Similarly four different effective areas were investigated: effective area at ambient $\left(A_{20}\right)$, elevated $\left(A_{t}\right)$, web $\left(A_{w}\right)$ and hot flange $\left(A_{h f}\right)$ temperatures. Table 2 shows the mechanical properties used in the calculation of these effective areas. Hence the local buckling capacities were predicted for 12 different cases (four effective areas x three yield stresses) using the relevant design rules in [16] and compared with FEA results in Figures 7 (a) to (d).

The local buckling capacities were too low when $f_{y h f}$ was used as the yield stress irrespective of the various effective areas used. On the other hand the capacity results were arbitrary when $A_{h f}$ was used. Hence it is not recommended to use the hot flange temperature in determining the effective widths of studs subjected to non-uniform temperature distribution. This reduced the number of cases to six.

Figure 8 shows the variation of yield stress with time. Four different tests are considered here (T1 - Externally insulated LSF wall with glass fibre; P1 - Non-insulated LSF wall with single layer of plasterboard; P2 - Non-insulated LSF wall with double layers of plasterboard; P3 Cavity insulated LSF wall with glass fibre). This figure compares the difference between $f_{y b a r}$ and $f_{y w e b}$. It indicates that there is a noticeable difference between using $f_{y b a r}$ and $f_{\text {yweb }}$. This difference is very high for cavity insulated wall panels. The appropriate yield stress to represent the cross section at non-uniform temperatures is $f_{y b a r}$ and Figure 8 suggests that it cannot be simplified by using $f_{\text {yweb }}$. This reduced the number of cases to three.

Figures 9(a) to (d) show the load ratio versus time curves for the short listed options $\left(f_{y b a r}\right.$ with At, $A_{w}$ and $A_{20}$ ) used to find the local buckling capacity of LSF wall studs with non-uniform temperature distributions. At higher load ratios the load ratio curve using the effective areas at elevated temperatures agreed well with FEA results compared to the load ratio curve using 
$A_{20}$. However, at lower load ratios none of them agreed with FEA results. This variation is much higher for cavity insulated wall panel (Figure 9(d)).

Figure 10 shows the von Mises stress distribution at failure for the cavity insulated wall panel. Table 3 presents the hot and cold flange temperatures and the corresponding yield stresses for different tests. The yield stress of the hot and cold flanges at failure (at 107 minutes) of Test 4* are $52 \mathrm{MPa}$ and $269 \mathrm{MPa}$, respectively. Figure 10 indicates that the entire hot flange has reached its yield strength capacity at this time and triggered the failure. However, at this time the cold flange has not reached its yield strength. This indicates that the cold flange has some reserve capacity at the time the stud failed. However, in the prediction of local buckling capacity at elevated temperatures according to $\sum A_{i} f_{y i}$, it is assumed that the entire stud cross-section has reached its yield stress. This resulted in the over-estimation of local buckling capacity of studs with non-uniform temperature distributions.

Table 4 shows the ultimate loads and load ratios obtained from FEA and the predictions based on the method using $f_{y b a r} * A_{t}$. The calculations using the proposed method can be found in [11]. The load ratio agreement was good during the initial phase of the tests. However, it was very poor during the final phase of all the tests. In this phase it was identified that the ratio of $f_{y C F} / f_{y H F}$ was greater than 1.5 (Table 3). Therefore it was decided to limit the yield stress of cold flange to $1.5 f_{y H F}$ during this phase in the determination of local buckling capacity. This indicates a better agreement in load ratios with FEA results.

Figure 11 shows the proposed method incorporated with the short-listed options to find the local buckling capacity. It clearly indicates that the effective area at ambient temperature $\left(A_{20}\right)$ is not suitable for determining the local buckling capacity of LSF wall studs at elevated temperatures. This figure also shows that the simplification of using effective area at average stud (web) temperature $\left(A_{w e b}\right)$ is too conservative compared to the effective area at elevated temperature $\left(A_{t}\right)$. Therefore it is concluded that effective element widths should be determined accurately using their respective elevated temperature properties. In summary the section compression capacity ( $N_{\text {eff }}$ ) of LSF wall stud under fire conditions can be determined using the product of the area based weighted average yield stress $f_{y b a r}$ and the effective area at elevated temperature, referred to as $A_{\text {eff,t }}$ in the following sections to indicate that it is effective 
area. Figures 9 (a) to (d) show a close agreement between the FEA results and the proposed method.

\subsection{Member Capacities of LSF Wall Studs under Fire Conditions}

Ranby [3] and Kaitila [5] used the mechanical properties at average stud (web) temperatures to find the member compression capacities of LSF wall studs subjected to non-uniform temperature distributions. However, Feng and Wang [6] and Zhao et al. [7] used the weighted average mechanical properties based on gross section dimensions. Figure 8 demonstrates that the weighted average mechanical properties should be used instead of the mechanical properties at web temperature. Hence in this study the weighted average mechanical properties were used with Eurocode 3 [16] design rules to determine the member compression capacities of LSF wall studs under fire conditions. These capacity calculations are given in [11].

\subsection{Section Moment Capacities of LSF Wall Studs under Fire Conditions}

Ranby [3] and Kaitila [5] used the basic formula $f_{y, w e b} Z_{\text {eff,20 }}$ to find the section moment capacities of LSF wall studs subject to non-uniform temperature distributions. They used the yield stress at web temperature and the effective section modulus at ambient temperature. The section modulus was calculated based on the effective element widths for pure compression. However, it is important that the effective element widths based on pure bending are used. Feng and Wang [6] suggested a more accurate method to find the section moment capacity. When calculating $M_{x, \text { eff }}$ at stud mid-height, compression is on the cold flange side with a high yield strength and tension is on the hot side with a low yield strength. In this case partial plasticity was considered whereby tensile stress in the extreme fibres has reached yield and the maximum compression stress in the extreme fibre is equal to the yield stress as shown in Figure 12. Alternatively the lower of first yield in either tension or compression is considered. In the current study the first option (partial plasticity) suggested in [6] was used in calculating the section moment capacity at mid-height. At the supports since the hot flange is in compression, the first yield of compression flange was adopted. Detail calculations according to Feng and Wang [6] are given in [11]. Zhao et al.'s [7] assumption was similar to that proposed in [6]. 
Figures 13 (a) to (d) show the interaction of compression and bending in four tests using the ratio of applied axial compression load and axial compression capacity $\left(N^{*} / N_{u}\right)$ and the ratio of applied bending moment and section moment capacity $\left(M^{*} / M_{u}\right)$. The influence of bending is high at mid-height compared at the support. Similarly the influence is high for LSF walls with cavity insulation compared to the externally insulated wall panels (Figures 13 (a) and (d)). However, overall, these figures clearly indicate that the LSF wall studs under nonuniform temperature distributions are dominated by compression than bending. Therefore it was decided to propose a simplified method to calculate the section moment capacity. It is proposed here that the section moment capacity at mid-height is calculated using the formula $\bar{f}_{y} \bar{Z}_{\text {eff }, t}$ where $\bar{f}_{y}$ is the area based weighted average yield stress (used as $f_{y b a r}$ in the earlier sections) and $\bar{Z}_{\text {eff }, t}$ is equal to $\bar{I}_{\text {eff }, t} / Y_{\max }$. In the studies of [6,7], partial plasticity was considered at mid-height whereby tensile stress in the extreme fibres has reached yield and the maximum compression stress in the extreme fibre is equal to the yield stress. Therefore in this scenario $\bar{f}_{y}$ is suitable to calculate the section moment capacity. $\bar{I}_{\text {eff }, t}$ is the weighted average second moment of area (taking into account the variation of elastic modulus with temperature across the section) calculated based on the effective element widths at elevated temperatures. The effective area for pure bending was calculated assuming compression on cold flange and these calculations can be found in [11].

In the studies of [6,7], the moment capacity at the support was calculated with yielding occurring in the hot flange. In this case $f_{y, H F}$ is suitable to calculate the section moment capacity instead of $\bar{f}_{y}$. Therefore it is proposed to calculate the section moment capacity at support using the formula $f_{y, H F} \bar{Z}_{\text {eff }, t}$. This time the effective area for pure bending should be calculated assuming compression on hot flange. This will introduce additional calculation effort without improving the accuracy much and hence not proposed in the current study. Therefore the effective area used in the mid-height calculations (assuming compression on cold flange) is also recommended for support calculations.

Figures 14 (a) to (d) show the variation of section moment capacity $\left(M_{\text {xeff }}\right)$ with time for four different tests according to [6] and the current simplified proposal for both mid-height and supports. A reasonable agreement was achieved between the accurate method of Feng and 
Wang [6] and the proposed simplified method in this section. Figures 15 (a) to (d) show the variation of ultimate compression capacities $\left(N_{E d}\right)$ of LSF wall studs with time at mid-height and supports for the same tests. It is very clear that the ultimate compression capacities were not affected by using the simplified method for section moment capacities. This is due to the fact that the LSF wall studs subjected to non-uniform temperature distributions are dominated by compression rather than bending as shown in Figures 13 (a) to (d). Therefore it is concluded that the section moment capacities can be calculated using the simplified method proposed here without affecting the accuracy of ultimate compression capacities of LSF wall studs.

\subsection{Interaction of Compression and Bending}

The effect of thermal bowing can be considered as that of an initial geometric imperfection of a slender member with pinned ends. The sinusoidal initial deformed shape is represented by,

$$
y_{o}=e_{\Delta T} \sin \left(\frac{\pi x}{L}\right)
$$

where $e_{\Delta T}$ is the thermal bowing at mid-height given by $e_{\Delta T}=\frac{\alpha L^{2} \delta T}{8 b_{w}}$ [21] where $\alpha$ is the thermal expansion coefficient for steel; $L$ and $b_{w}$ are the stud height and web depth, respectively, and $\delta T$ is the temperature difference.

In this case the maximum total deformation $\left(e_{1}\right)$ is obtained at mid-height by [22],

$$
e_{1}=\frac{e_{\Delta T}}{1-\frac{N_{E d}}{N_{c r}}}
$$

where $N_{E d}$ is the applied load and $N_{c r}$ is the Euler buckling load.

Hence the bending moment generated by thermal bowing and its magnification effect is given by

$$
N_{E d} e_{1}=\frac{N_{E d} e_{\Delta T}}{1-\frac{N_{E d}}{N_{c r}}}
$$

Using Eurocode 3 [16] the bending moment due to the shift of neutral axis about the major axis and its magnification effects is given by

$N_{E d} e_{2}=k_{x x} N_{E d} e_{\Delta E}$

assuming the LSF wall stud is not susceptible to torsional deformation, 
where $e_{\Delta E}=\frac{\sum_{i} E_{i, \theta} y_{i} A_{i}}{\sum_{i} E_{i, \theta} A_{i}}$ and $k_{x x}=\frac{C_{m x}}{1-\chi_{x} \frac{N_{E d}}{N_{c r}}}$ where $C_{m x}$ allows for the effects of nonuniform distribution and applied axial compression load.

$C_{m x}=0.79+0.21 \psi+0.36(\psi-0.33) \frac{N_{E d}}{N_{c r}}$ where $\psi=1$ in this study since the moment due to neutral axis shift is equal at both ends.

Therefore the total moment due to thermal bowing, neutral axis shift and their magnification effects can be calculated as,

$$
M_{x E d t o t}=N_{E d}\left(e_{1}-e_{2}\right)=\frac{N_{E d} e_{\Delta T}}{1-\frac{N_{E d}}{N_{c r}}}-\frac{N_{E d} e_{\Delta E} C_{m x}}{1-\chi_{x} \frac{N_{E d}}{N_{c r}}}
$$

In this study, the equations given in Eurocode 3 [16] are reduced to Equation 9 to obtain the ultimate compression capacities $\left(N_{E d}\right)$ of LSF wall studs subjected to non-uniform temperature distributions.

$$
\frac{N_{E d}}{\chi_{x} N_{e f f}}+\frac{M_{x E d t o t}}{M_{x, e f f}}=1
$$

where

$N_{\text {eff, }} \chi_{x}, M_{x, \text { eff }}$ and $M_{x E d t o t}$ are obtained as discussed in Sections 4.1, 4.2, 4.3 and 4.4, respectively.

In the studies of $[3,5]$, the magnification effects were counted twice by the use of the factors $\frac{1}{1-\frac{N_{E d}}{N_{c r}}}$ and $k_{x x}$. This is not recommended in the fire design of LSF wall studs and hence the proposed method in this section should be used.

\subsection{Thermal Bowing, Neutral Axis Shift and Magnification Effects}

When the axial compression load is applied at the original centroid of the cross-section, the effective eccentricity in LSF wall studs under non-uniform temperature conditions can be developed due to thermal bowing, neutral axis shift and magnification effects. In the studies of $[1,2]$, only the thermal bowing and its magnification effects were considered in the fire 
design of LSF wall studs. However, all three effects were considered in [3-7]. In this study the effect of these parameters was investigated as four different cases (Table 5).

Figure 16 shows the variation of load ratios with respect to time using these four different effective eccentricities. When the magnification effect of thermal bowing was ignored the failure time was significantly overestimated. On the other hand when the neutral axis shift was ignored a better agreement was obtained with FEA results (compare Cases 1 and 3). However, this is unlikely to be the case for all the LSF wall configurations and hence this study recommends the inclusion of all three effects in the fire design of LSF wall panels as they all play a role when the stud is subjected to non-uniform temperature distributions.

\section{Proposed Fire Design Rules based on AS/NZS 4600 [14] and NAS [15]}

Both Klippstein [1] and Gerlich et al. [2] developed fire design rules for LSF wall studs using the AISI design manual. The fire design calculations using their proposals can be found in [11]. The equations used in [1] are not available in the North American Specification [15]. Gerlich et al. [2] calculated the critical stress and the bending moment capacity based on the yield stress at cold flange temperature. This resulted in the over-estimation of failure times of LSF wall panels. In this section suitable fire design rules are proposed based on the ambient temperature cold-formed steel design codes AS/NZS 4600 [14] and NAS [15] that have identical design provisions.

As discussed in Section 4, Equation 10 is proposed here to obtain the ultimate compression capacities of LSF wall studs subjected to non-uniform temperature distributions. It is based on Equation 9 but rewritten using the symbols used in [14,15].

$\frac{N^{*}}{A_{e f f, t} f_{n}}+\frac{M^{*}}{M_{x, e f f}}=1$

where $N^{*}$ and $M^{*}$ are the applied axial compression load and the total moment about the major axis; $f_{n}$ is calculated based on the weighted average mechanical properties (yield stress and elastic modulus) at elevated temperatures and includes the effects of major axis flexural buckling; $A_{e f f, t}$ is the effective area at elevated temperature calculated as discussed in Section 4.1 using $f_{n}$; The determination of member compression capacity using [14] is much simpler than using [16], since the Australian design code finds the member capacity directly using $f_{n}$ 
rather than finding it from the section capacity as is done in European design code. $M_{x, \text { eff }}$ is the section moment capacity calculated as discussed in Section 4.3;

The total moment $M^{*}$ due to thermal bowing, neutral axis shift and their magnification effects is given by

$$
M^{*}=\frac{C_{m x} N^{*} e}{\alpha_{n x}}=\frac{N^{*} e_{\Delta T}}{1-\frac{N^{*}}{N_{c r}}}-\frac{N^{*} e_{\Delta E}}{1-\frac{N^{*}}{N_{c r}}}
$$

where $C_{m x}$ is equal to 1 in the case of neutral axis shift as the moments developed in this case is uniform while the total moment due to thermal bowing is shown to be $\frac{N^{*} e_{\Delta T}}{1-\frac{N^{*}}{N_{c r}}}$ (Equation 6). Detailed calculations to find the ultimate capacity of LSF wall studs at elevated temperatures using AS/NZS 4600 [14] design rules are given in [11].

Figures 17 (a) to (j) compare the variation of FEA load ratios with predicted load ratios based on Australian and European codes [14,16]. A reasonable agreement was obtained between the FEA results and the predictions. A very good agreement was obtained between [14] and [16] although the latter is slightly conservative in predicting the failure times for lower load ratios.

\section{Discussions}

\subsection{Comparison of Previous and Proposed Fire Design Rules}

Table 6 shows the effective areas used in the previous and the proposed fire design rules. It shows the different effective areas used in finding the compression and section moment capacities. Table 7 shows the parameters and assumptions used with these fire design rules including thermal bowing, neutral axis shift and magnification effects. Effects of the varying assumptions and parameters used in the previous design rules was investigated in detail for the tests reported in Table 1 , and the results are given in $[9,11]$.

Tables 8 and 9 compare the test and FEA results with the predicted failure times (FRR) using the proposed fire design rules based on [14] and [16], respectively. The agreement is very good and it is concluded that the proposed fire design rules using [14] and [16] accurately predict the failure times of LSF wall panels subject to fire from one side. 


\subsection{Proposed Fire Design Rules for Different Steel Grades and Thicknesses}

In this section the developed fire design rules based on [14] and [16] will be further validated for LSF wall studs with varying structural parameters such as steel grade and thickness (1.15 and $1.95 \mathrm{~mm}$ G250 steel). A nominal yield stress of $250 \mathrm{MPa}$ was assumed at ambient temperature. The strain hardening model was used for steels with gradual yielding type stressstrain curve except for $\mathrm{G} 250$ steels at $20^{\circ} \mathrm{C}, 100^{\circ} \mathrm{C}$ and $200^{\circ} \mathrm{C}$, which have a well defined yield point. Hence an elastic-perfect plastic material model was used in these three cases [18]. In the analyses the idealised time-temperature profiles proposed in $[9,11]$ were used.

Figures 18 and 19 compare the predictions from the proposed fire design rules with FEA results for $1.15 \mathrm{~mm}$ and $1.95 \mathrm{~mm}$ G250 steel stud walls with the eight different configurations shown in Table 1. Although there was a variation between the actual ultimate loads, the load ratios from FEA and the proposed fire design rules agreed reasonably well with each other. The agreement between the proposed fire design rules based on [14] and [16] was also very good.

Tables 10 and 11 show the failure times predicted for $1.15 \mathrm{~mm}$ and $1.95 \mathrm{~mm}$ G250 steel studs for the load ratios of $0.2,0.4$ and 0.7 , respectively. It can be seen that the predicted failure times using the proposed fire design rules based on [14] and [16] agreed well with FEA results.

\section{Conclusions}

This research has presented the details of an investigation on the development of improved fire design rules for LSF walls under standard fire conditions. The behaviour and capacity of LSF wall studs subjected to non-uniform elevated temperature conditions during standard fires was evaluated in detail based on a series of full scale fire tests and extensive numerical studies and comparison with previous fire design rules developed based on American and European design codes. New simplified fire design rules were proposed based on AS/NZS 4600, North American Specification and Eurocode 3 Part 1.3 with suitable allowances for the interaction effects of compression and bending actions and the effects of thermal bowing, neutral axis shift and their magnification effects. The accuracy of the proposed fire design rules was verified with the available test and FEA results for LSF wall systems made of eight 
different wall configurations and varying steel grades and thicknesses. The agreement of failure times was very good compared to the complexity and assumptions involved in the fire deign of LSF wall studs. This paper has demonstrated significant improvements to the design method when compared to the prescriptive design methods for LSF wall systems under fire conditions.

\section{Acknowledgements}

The authors would like to thank Australian Research Council for their financial support and the Queensland University of Technology for providing the necessary facilities and support to conduct this research project.

\section{References}

[1] Klippstein, K.H. (1980), Strength of Cold-Formed Studs Exposed to Fire, American Iron and Steel Institute. Washington DC, USA.

[2] Gerlich, J.T., Collier, P.C.R. and Buchanan, A.H. (1996), Design of Steel-framed Walls for Fire Resistance, Fire and Materials, Vol.20, No.2, pp.79-96.

[3] Ranby, A. (1999), Structural Fire Design of Thin-Walled Steel Sections, Licentiate Thesis, Department of Civil and Mining Engineering, Lulea University of Technology, Stockholm, Sweden.

[4] Wang, Y.C. and Davies, J.M. (2000), Design of thin-walled steel channel columns in fire using Eurocode 3 Part 1.3, Proceedings of the First International Workshop on Structures in Fire, Copenhagen, pp.181-93.

[5] Kaitila, O. (2002), Finite Element Modelling of Cold-formed Steel Members at High Temperatures, Licentiate Thesis, Helsinki University of Technology Laboratory of Steel Structures, Espoo, Finland.

[6] Feng, M. and Wang, Y.C. (2005), An Analysis of the Structural Behaviour of Axially Loaded Full-scale Cold-formed Thin-walled Steel Structural Panels Tested under Fire Conditions, Thin-Walled Structures, Vol.43, pp.291-332. 
[7] Zhao, B., Kruppa, J., Renaud, C., O’Connor, M., Mecozzi, E., Apiazu,. W., Demarco, T., Karlstrom, P., Jumppanen, U., Kaitila, O., Oksanen, T. and Salmi, P. (2005), Calculation rules of lightweight steel sections in fire situations, Technical steel research, European Union.

[8] Alfawakhiri, F. (2001), Behaviour of Cold-formed-Steel-framed Walls and Floors in Standard Fire Resistance Tests, PhD Thesis. Department of Civil and Environmental Engineering, Carleton University, Ottawa, Canada.

[9] Gunalan, S. and Mahendran, M. (2013), Review of Fire Design Rules for LSF Wall Systems, Journal of Fire Science, Accepted.

[10]Kolarkar, P.N. (2010), Structural and Thermal Performance of Cold-formed Steel Stud Wall Systems under Fire Conditions, PhD Thesis, Queensland University of Technology, Brisbane, Australia.

[11] Gunalan, S. (2011), Structural Behaviour and Design of Cold-formed Steel Wall Systems under Fire Conditions, PhD Thesis, Queensland University of Technology, Brisbane, Australia.

[12] Gunalan, S., Kolarkar, P.N. and Mahendran, M. (2013), Experimental Study of Load Bearing Cold-formed Steel Wall Systems under Fire Conditions, Thin-Walled Structures, Accepted.

[13] Gunalan, S. and Mahendran, M. (2013), Finite Element Modelling of Load Bearing Cold-formed Steel Wall Systems under Fire Conditions, Engineering Structures, Accepted.

[14] Standards Australia (SA) (2005), AS/NZS 4600 Cold-formed Steel Structures, Sydney, Australia. 
[15] American Iron and Steel Institute (AISI) (2007), North American Specifications for the Design of Cold-formed Steel Structural Members (NAS), Washington DC, USA.

[16] EN 1993-1-3 (2006), Eurocode 3: Design of Steel Structures. Part 1-3: General Rules Supplementary Rules for Cold-formed Members and Sheeting, European Committee for Standardization, Brussels, Belgium.

[17] Standards Australia (2005), AS 1530.4 Methods for Fire Tests on Building Materials, Components and Structures Part 4, Sydney, Australia.

[18] Dolamune Kankanamge, N. and Mahendran, M. (2011), Mechanical Properties of Coldformed Steels at Elevated Temperatures, Thin-Walled Structures, Vol.49, pp.26-44.

[19]EN 1993-1-2 (2005), Eurocode 3: Design of Steel Structures. Part 1-2: General Rules Structural Fire Design, European Committee for Standardization, Brussels, Belgium.

[20]Feng, M., Wang, Y.C. and Davies, J.M. (2003), Axial Strength of Cold-formed Thinwalled Steel Channels under Non-uniform Temperatures in Fire, Fire Safety Journal, Vol.38, pp.679-707.

[21]Cooke, G.M.E. (1987), Thermal Bowing and How it Affects the Design of Fire Separating Construction, Fire Research Station, Building Research Establishment, Herts, UK.

[22]Luis, S.S., Rui, S. and Helana, G. (2010), Design of Steel Structures, European Convention for Constructional Steelwork (ECCS), Belgium. 
Table 1: Failure Times from Experiments and FEA

\begin{tabular}{|c|c|c|c|c|c|}
\hline \multirow{2}{*}{ Test } & \multirow{2}{*}{ Configuration } & \multirow{2}{*}{ Insulation } & \multirow{2}{*}{$\begin{array}{l}\text { Load } \\
\text { Ratio }\end{array}$} & \multicolumn{2}{|c|}{ Failure Time (min.) } \\
\hline & & & & Test & FEA \\
\hline 1 & (1) & Glass Fibre & 0.2 & 118 & 115 \\
\hline 2 & $\begin{array}{lll}\cdots & \\
& & \\
\end{array}$ & Glass Fibre & 0.4 & 108 & 110 \\
\hline 3 & $\frac{m}{5}$ & Rock Fibre & 0.4 & 134 & 131 \\
\hline $1^{*}$ & $\left.\begin{array}{lllll} & {[} & {[} & {[} & 1\end{array}\right]$ & None & 0.2 & 53 & 53 \\
\hline $2 *$ & 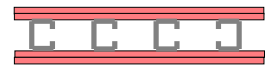 & None & 0.2 & 111 & 115 \\
\hline $3 *$ & $1 \because \because \because \cdots$ & Glass Fibre & 0.2 & 101 & 100 \\
\hline $4^{*}$ & $\operatorname{la} \because \because \cdots$ & Rock Fibre & 0.2 & 107 & 105 \\
\hline $5 *$ & 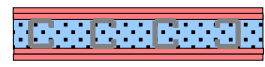 & Cellulose Fibre & 0.2 & 110 & 109 \\
\hline $6^{*}$ & $\begin{array}{l}\mathrm{C} C \mathrm{C} \\
\end{array}$ & Rock Fibre & 0.2 & $136^{\#}$ & 154 \\
\hline $7 *$ & 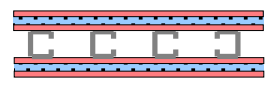 & Cellulose Fibre & 0.2 & 124 & 129 \\
\hline
\end{tabular}

Tests 1 - 3 conducted by Gunalan [11]; Tests $1 *$ - 7* conducted by Kolarkar [10]; (\# ) - Earlier Failure Time due to Lack of Thermal Expansion 
Table 2: Mechanical Properties Used in the Calculations of Effective Areas

\begin{tabular}{|c|c|c|c|c|}
\hline Elfective Areas & $A_{20}$ & $A_{t}$ & $A_{w}$ & $A_{h f}$ \\
\hline Web & $f_{y 20}, E_{20}$ & $f_{y w e b}, E_{w e b}$ & $f_{y w e b}, E_{w e b}$ & $f_{y h f}, E_{h f}$ \\
\hline Hot Flange and Lip & $f_{y 20}, E_{20}$ & $f_{y h f}, E_{h f}$ & $f_{y w e b}, E_{w e b}$ & $f_{y h f}, E_{h f}$ \\
\hline Cold Flange and Lip & $f_{y 20}, E_{20}$ & $f_{y c f}, E_{c f}$ & $f_{y w e b}, E_{w e b}$ & $f_{y h f}, E_{h f}$ \\
\hline
\end{tabular}


Table 3: Yield Stresses of Hot and Cold Flanges

\begin{tabular}{|c|c|c|c|c|c|c|c|}
\hline Test & $\begin{array}{l}\text { Time } \\
\text { (min.) }\end{array}$ & $\begin{array}{l}\mathrm{HF} \\
\left({ }^{\circ} \mathrm{C}\right)\end{array}$ & $\begin{array}{l}\mathrm{CF} \\
\left({ }^{\circ} \mathrm{C}\right)\end{array}$ & $\begin{array}{c}\text { HF-CF } \\
\left({ }^{\circ} \mathrm{C}\right)\end{array}$ & $\begin{array}{c}f_{y H F} \\
(\mathrm{MPa})\end{array}$ & $\begin{array}{c}f_{y C F} \\
(\mathrm{MPa})\end{array}$ & $f_{y C F} / f_{y H F}$ \\
\hline \multirow{8}{*}{1} & 0 & 20 & 20 & 0 & 569 & 569 & 1.00 \\
\hline & 30 & 71 & 56 & 15 & 569 & 569 & 1.00 \\
\hline & 60 & 182 & 111 & 71 & 565 & 569 & 1.01 \\
\hline & 70 & 218 & 132 & 86 & 561 & 568 & 1.01 \\
\hline & 90 & 368 & 240 & 128 & 450 & 558 & 1.24 \\
\hline & 97 & 418 & 296 & 122 & 363 & 543 & 1.50 \\
\hline & 110 & 537 & 394 & 143 & 162 & 405 & 2.50 \\
\hline & 118 & 656 & 492 & 164 & 50 & 236 & 4.72 \\
\hline \multirow{7}{*}{$1 *$} & 0 & 20 & 20 & 0 & 569 & 569 & 1.00 \\
\hline & 9 & 97 & 74 & 23 & 569 & 569 & 1.00 \\
\hline & 20 & 184 & 88 & 96 & 565 & 569 & 1.01 \\
\hline & 30 & 346 & 187 & 159 & 486 & 565 & 1.16 \\
\hline & 46 & 535 & 346 & 189 & 165 & 486 & 2.95 \\
\hline & 50 & 570 & 395 & 175 & 109 & 404 & 3.71 \\
\hline & 53 & 595 & 467 & 128 & 71 & 278 & 3.92 \\
\hline \multirow{7}{*}{$2 *$} & 0 & 20 & 20 & 0 & 569 & 569 & 1.00 \\
\hline & 30 & 93 & 83 & 10 & 569 & 569 & 1.00 \\
\hline & 60 & 215 & 128 & 87 & 562 & 568 & 1.01 \\
\hline & 80 & 354 & 259 & 95 & 473 & 554 & 1.17 \\
\hline & 90 & 416 & 313 & 103 & 367 & 531 & 1.45 \\
\hline & 105 & 497 & 408 & 89 & 227 & 381 & 1.68 \\
\hline & 111 & 555 & 446 & 109 & 133 & 314 & 2.36 \\
\hline \multirow{7}{*}{$4^{*}$} & 0 & 20 & 20 & 0 & 569 & 569 & 1.00 \\
\hline & 60 & 165 & 91 & 74 & 567 & 569 & 1.00 \\
\hline & 80 & 388 & 162 & 226 & 416 & 567 & 1.36 \\
\hline & 90 & 476 & 200 & 276 & 263 & 564 & 2.14 \\
\hline & 94 & 515 & 213 & 302 & 197 & 562 & 2.85 \\
\hline & 100 & 590 & 238 & 352 & 78 & 558 & 7.15 \\
\hline & 107 & 648 & 269 & 379 & 52 & 551 & 10.6 \\
\hline
\end{tabular}


Table 4: Comparison of FEA with Current and Proposed Design Rules

\begin{tabular}{|c|c|c|c|c|c|c|c|}
\hline \multirow{2}{*}{ Test } & \multirow{2}{*}{ Time } & \multicolumn{2}{|c|}{ FEA } & \multicolumn{2}{|c|}{$f_{y b a r} * A_{t}$} & \multicolumn{2}{|c|}{ Proposed } \\
\hline & & Load & LR & Load & LR & Load & LR \\
\hline \multirow{8}{*}{1} & 0 & 77.9 & 1.00 & 74.7 & 1.00 & 74.7 & 1.00 \\
\hline & 30 & 77.1 & 0.99 & 73.3 & 0.98 & 73.3 & 0.98 \\
\hline & 60 & 75.6 & 0.97 & 70.3 & 0.94 & 70.3 & 0.94 \\
\hline & 70 & 74.7 & 0.96 & 68.9 & 0.92 & 68.9 & 0.92 \\
\hline & 90 & 64.7 & 0.83 & 59.7 & 0.80 & 59.3 & 0.79 \\
\hline & 97 & 57.1 & 0.73 & 53.4 & 0.71 & 52.9 & 0.71 \\
\hline & 110 & 32.1 & 0.41 & 37.8 & 0.51 & 30.0 & 0.40 \\
\hline & 118 & 13.9 & 0.18 & 20.4 & 0.27 & 12.4 & 0.17 \\
\hline \multirow{7}{*}{$1^{*}$} & 0 & 77.9 & 1.00 & 74.7 & 1.00 & 74.7 & 1.00 \\
\hline & 9 & 76.6 & 0.98 & 72.5 & 0.97 & 72.5 & 0.97 \\
\hline & 20 & 75.7 & 0.97 & 70.6 & 0.95 & 70.6 & 0.95 \\
\hline & 30 & 68.1 & 0.87 & 62.7 & 0.84 & 62.4 & 0.84 \\
\hline & 46 & 36.9 & 0.47 & 42.3 & 0.57 & 31.2 & 0.42 \\
\hline & 50 & 25.8 & 0.33 & 35.7 & 0.48 & 23.8 & 0.32 \\
\hline & 53 & 20.2 & 0.26 & 26.5 & 0.35 & 17.4 & 0.23 \\
\hline \multirow{7}{*}{$2 *$} & 0 & 77.9 & 1.00 & 74.7 & 1.00 & 74.7 & 1.00 \\
\hline & 30 & 76.6 & 0.98 & 72.4 & 0.97 & 72.4 & 0.97 \\
\hline & 60 & 74.8 & 0.96 & 69.1 & 0.93 & 69.1 & 0.93 \\
\hline & 80 & 65.4 & 0.84 & 59.6 & 0.80 & 59.3 & 0.79 \\
\hline & 90 & 56.5 & 0.73 & 52.5 & 0.70 & 52.1 & 0.70 \\
\hline & 105 & 39.0 & 0.50 & 39.2 & 0.52 & 37.1 & 0.50 \\
\hline & 111 & 26.8 & 0.34 & 31.7 & 0.42 & 25.8 & 0.35 \\
\hline \multirow{7}{*}{$4^{*}$} & 0 & 77.9 & 1.00 & 74.7 & 1.00 & 74.7 & 1.00 \\
\hline & 60 & 75.6 & 0.97 & 70.9 & 0.95 & 70.9 & 0.95 \\
\hline & 80 & 64.8 & 0.83 & 61.4 & 0.82 & 60.6 & 0.81 \\
\hline & 90 & 51.2 & 0.66 & 55.6 & 0.74 & 46.7 & 0.63 \\
\hline & 94 & 44.4 & 0.57 & 52.7 & 0.71 & 39.1 & 0.52 \\
\hline & 100 & 27.1 & 0.35 & 47.5 & 0.64 & 24.3 & 0.33 \\
\hline & 107 & 19.2 & 0.25 & 42.1 & 0.56 & 18.7 & 0.25 \\
\hline
\end{tabular}


Table 5: Effective Eccentricities Considered in this Study

\begin{tabular}{|c|c|}
\hline Case & Effective Eccentricity \\
\hline 1 & $\begin{array}{l}\text { Thermal bowing, Magnification effects and Neutral axis shift } \\
\text { are included }\left(e_{\Delta T}+e_{P \Delta T}-e_{\Delta E}\right)\end{array}$ \\
\hline 2 & $\begin{array}{l}\text { Thermal bowing and Neutral Axis Shift are included } \\
\qquad\left(e_{\Delta T}-e_{\Delta E}\right)\end{array}$ \\
\hline 3 & $\begin{array}{l}\text { Thermal bowing and Magnification effects are included } \\
\qquad\left(e_{\Delta T}+e_{P \Delta T}\right)\end{array}$ \\
\hline 4 & Only Thermal bowing effect is included $e_{\Delta T}$ \\
\hline
\end{tabular}


Table 6: Effective Areas in Previous and Proposed Fire Design Rules

\begin{tabular}{|c|c|c|}
\hline $\begin{array}{l}\text { Previous Fire } \\
\text { design Rules }\end{array}$ & $\begin{array}{c}\text { Effective Area for } \\
\text { Compression Capacity }\end{array}$ & $\begin{array}{c}\text { Section Modulus } \mathrm{Z}_{\mathrm{eff}} \text { for } \\
\text { Bending Capacity }\end{array}$ \\
\hline Klippstein [1] & $\begin{array}{c}\text { Effective area was calculated } \\
\text { assuming uniform compression } \\
\text { at elevated temperatures }\end{array}$ & Gross area was used \\
\hline $\begin{array}{l}\text { Gerlich et al. } \\
\text { [2] }\end{array}$ & $\begin{array}{l}\text { Effective area was calculated } \\
\text { assuming uniform compression } \\
\text { at ambient temperatures }\end{array}$ & Gross area was used \\
\hline Ranby [3] & $\begin{array}{l}\text { Effective area was calculated } \\
\text { assuming uniform compression } \\
\text { at ambient temperatures }\end{array}$ & $\begin{array}{l}\text { Effective area was calculated } \\
\text { assuming uniform compression } \\
\text { at ambient temperatures }\end{array}$ \\
\hline Kaitila [5] & $\begin{array}{l}\text { Effective area was calculated } \\
\text { assuming uniform compression } \\
\text { at ambient temperatures }\end{array}$ & $\begin{array}{l}\text { Effective area was calculated } \\
\text { assuming uniform compression } \\
\text { at ambient temperatures }\end{array}$ \\
\hline $\begin{array}{c}\text { Feng and } \\
\text { Wang [6] } \\
\text { Eurocode } 3 \\
\text { Part } 1.2\end{array}$ & $\begin{array}{l}\text { Effective area was calculated } \\
\text { assuming uniform compression } \\
\text { at ambient temperatures }\end{array}$ & $\begin{array}{l}\text { Effective area was calculated } \\
\text { assuming pure bending at } \\
\text { ambient temperatures }\end{array}$ \\
\hline $\begin{array}{c}\text { Feng and } \\
\text { Wang [6] } \\
\text { Eurocode } 3 \\
\text { Part } 1.3\end{array}$ & $\begin{array}{c}\text { Effective area was calculated } \\
\text { assuming uniform compression } \\
\text { at elevated temperatures }\end{array}$ & $\begin{array}{l}\text { Effective area was calculated } \\
\text { assuming pure bending at } \\
\text { elevated temperatures }\end{array}$ \\
\hline Zhao et al. [7] & $\begin{array}{c}\text { Effective area was calculated } \\
\text { assuming uniform compression } \\
\text { at elevated temperatures }\end{array}$ & $\begin{array}{c}\text { Effective area was calculated } \\
\text { assuming pure bending at } \\
\text { elevated temperatures }\end{array}$ \\
\hline $\begin{array}{l}\text { Proposed in } \\
\text { the Current } \\
\text { Study }\end{array}$ & $\begin{array}{l}\text { Effective area was calculated } \\
\text { assuming uniform compression } \\
\text { at elevated temperatures }\end{array}$ & $\begin{array}{l}\text { Effective area was calculated } \\
\text { assuming pure bending at } \\
\text { elevated temperatures }\end{array}$ \\
\hline
\end{tabular}


Table 7: Comparison of Previous and Proposed Fire Design Rules

\begin{tabular}{|c|c|c|c|c|c|c|c|c|}
\hline $\begin{array}{c}\text { Fire Design } \\
\text { Rules }\end{array}$ & $\begin{array}{c}\text { Klippstein } \\
\text { [1] }\end{array}$ & $\begin{array}{c}\text { Gerlich et } \\
\text { al. [2] }\end{array}$ & Ranby [3] & Kaitila [5] & $\begin{array}{l}\text { Feng and } \\
\text { Wang [6] }\end{array}$ & $\begin{array}{l}\text { Feng and } \\
\text { Wang [6] }\end{array}$ & Zhao et al. [7] & $\begin{array}{l}\text { Proposed Fire } \\
\text { Design Rules }\end{array}$ \\
\hline $\begin{array}{c}\text { Standard } \\
\text { Used }\end{array}$ & AISI & AISI & $\begin{array}{c}\text { EC3 } \\
\text { Part } 1.3\end{array}$ & $\begin{array}{c}\text { EC3 } \\
\text { Part } 1.3\end{array}$ & $\begin{array}{c}\text { EC3 } \\
\text { Part } 1.2\end{array}$ & $\begin{array}{c}\text { EC3 } \\
\text { Part } 1.3\end{array}$ & $\begin{array}{c}\text { EC3 } \\
\text { Part } 1.3\end{array}$ & $\begin{array}{c}\text { AS/NZS } 4600 \\
\text { EC3 Part } 1.3\end{array}$ \\
\hline Yield Stress & $\begin{array}{c}\text { Yield stress } \\
\text { at average } \\
\text { stud } \\
\text { temperature }\end{array}$ & $\begin{array}{l}\text { Yield stress } \\
\text { at cold } \\
\text { flange } \\
\text { temperature }\end{array}$ & $\begin{array}{l}\text { Yield stress } \\
\text { at average } \\
\text { stud } \\
\text { temperature }\end{array}$ & $\begin{array}{l}\text { Yield stress } \\
\text { at average } \\
\text { stud } \\
\text { temperature }\end{array}$ & $\begin{array}{c}\text { Weighted } \\
\text { average yield } \\
\text { stress at } \\
\text { elevated } \\
\text { temperature }\end{array}$ & $\begin{array}{c}\text { Weighted } \\
\text { average yield } \\
\text { stress at } \\
\text { elevated } \\
\text { temperature }\end{array}$ & $\begin{array}{c}\text { Weighted } \\
\text { average yield } \\
\text { stress at } \\
\text { elevated } \\
\text { temperature }\end{array}$ & $\begin{array}{c}\text { Weighted } \\
\text { average yield } \\
\text { stress at } \\
\text { elevated } \\
\text { temperature }\end{array}$ \\
\hline $\begin{array}{l}\text { Elastic } \\
\text { Modulus }\end{array}$ & $\begin{array}{c}\text { Elastic } \\
\text { modulus at } \\
\text { average stud } \\
\text { temperature }\end{array}$ & $\begin{array}{c}\text { Elastic } \\
\text { modulus at } \\
\text { average } \\
\text { stud } \\
\text { temperature }\end{array}$ & $\begin{array}{c}\text { Elastic } \\
\text { modulus at } \\
\text { average } \\
\text { stud } \\
\text { temperature }\end{array}$ & $\begin{array}{c}\text { Elastic } \\
\text { modulus at } \\
\text { average stud } \\
\text { temperature }\end{array}$ & $\begin{array}{c}\text { Weighted } \\
\text { average elastic } \\
\text { modulus at } \\
\text { elevated } \\
\text { temperature }\end{array}$ & $\begin{array}{c}\text { Weighted } \\
\text { average elastic } \\
\text { modulus at } \\
\text { elevated } \\
\text { temperature }\end{array}$ & $\begin{array}{c}\text { Weighted } \\
\text { average elastic } \\
\text { modulus at } \\
\text { elevated } \\
\text { temperature }\end{array}$ & $\begin{array}{c}\text { Weighted } \\
\text { average elastic } \\
\text { modulus at } \\
\text { elevated } \\
\text { temperature }\end{array}$ \\
\hline $\begin{array}{l}\text { Thermal } \\
\text { bowing }\end{array}$ & Considered & Considered & Considered & Considered & Considered & Considered & Considered & Considered \\
\hline $\begin{array}{c}\text { Magnification } \\
\text { effects }\end{array}$ & Considered & Considered & Considered & Considered & Considered & Considered & Considered & Considered \\
\hline $\begin{array}{c}\text { Neutral axis } \\
\text { shift }\end{array}$ & $\begin{array}{c}\text { Not } \\
\text { Considered }\end{array}$ & $\begin{array}{c}\text { Not } \\
\text { Considered }\end{array}$ & Considered & Considered & Considered & Considered & Considered & Considered \\
\hline $\begin{array}{l}\text { Capacity } \\
\text { Checks at }\end{array}$ & Mid-height & Mid-height & Mid-height & Mid-height & $\begin{array}{l}\text { Mid-height } \\
\text { and Stud End }\end{array}$ & $\begin{array}{l}\text { Mid-height } \\
\text { and Stud End }\end{array}$ & $\begin{array}{l}\text { Mid-height } \\
\text { and Stud End }\end{array}$ & $\begin{array}{l}\text { Mid-height } \\
\text { and Stud End }\end{array}$ \\
\hline
\end{tabular}


Table 8: Failure Times Predicted by the Proposed Fire Design Rules Using AS/NZS 4600 [15]

\begin{tabular}{|c|c|c|c|c|c|c|c|c|c|c|c|c|c|c|c|c|c|}
\hline \multirow{3}{*}{ Test } & \multirow{3}{*}{ Configuration } & \multirow{3}{*}{ Insulation } & \multicolumn{5}{|c|}{ Load Ratio $=0.2$} & \multicolumn{5}{|c|}{ Load Ratio $=0.4$} & \multicolumn{5}{|c|}{ Load Ratio $=0.7$} \\
\hline & & & \multicolumn{3}{|c|}{$\begin{array}{l}\text { Failure Time } \\
\text { (min.) }\end{array}$} & \multicolumn{2}{|c|}{ Ratio } & \multicolumn{3}{|c|}{$\begin{array}{l}\text { Failure Time } \\
\text { (min.) }\end{array}$} & \multicolumn{2}{|c|}{ Ratio } & \multicolumn{3}{|c|}{$\begin{array}{l}\text { Failure Time } \\
\text { (min.) }\end{array}$} & \multicolumn{2}{|c|}{ Ratio } \\
\hline & & & Test & FEA & Prop. & $\mathrm{T} / \mathrm{P}$ & $\mathrm{F} / \mathrm{P}$ & Test & FEA & Prop. & $\mathrm{T} / \mathrm{P}$ & $\mathrm{F} / \mathrm{P}$ & Test & FEA & Prop. & $\mathrm{T} / \mathrm{P}$ & $\mathrm{F} / \mathrm{P}$ \\
\hline 1 & 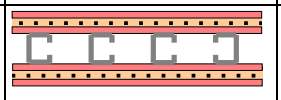 & $\begin{array}{l}\text { Glass } \\
\text { Fibre }\end{array}$ & 118 & 115 & 117 & 1.009 & 0.983 & - & 109 & 109 & - & 1.000 & - & 72 & 82 & - & 0.878 \\
\hline 2 & 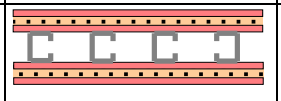 & $\begin{array}{l}\text { Glass } \\
\text { Fibre }\end{array}$ & - & 116 & 116 & - & 1.000 & 108 & 110 & 111 & 0.973 & 0.991 & - & 85 & 92 & - & 0.924 \\
\hline 3 & 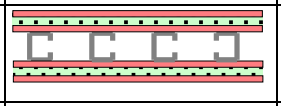 & $\begin{array}{l}\text { Rock } \\
\text { Fibre }\end{array}$ & - & 143 & 137 & - & 1.044 & 134 & 131 & 132 & 1.015 & 0.992 & - & 95 & 101 & - & 0.941 \\
\hline $1 *$ & Li & None & 53 & 53 & 56 & 0.946 & 0.946 & - & 42 & 44 & - & 0.955 & - & 20 & 25 & - & 0.800 \\
\hline $2 *$ & 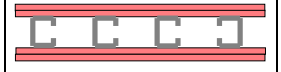 & None & 111 & 115 & 116 & 0.957 & 0.991 & - & 107 & 108 & - & 0.991 & - & 63 & 73 & - & 0.863 \\
\hline $3 *$ & $\alpha \because \because \because \because 6$ & $\begin{array}{l}\text { Glass } \\
\text { Fibre }\end{array}$ & 101 & 100 & 97 & 1.041 & 1.031 & - & 88 & 91 & - & 0.967 & - & 62 & 67 & - & 0.925 \\
\hline $4^{*}$ & $\therefore \because \cdots \because \cdots$ & $\begin{array}{l}\text { Rock } \\
\text { Fibre }\end{array}$ & 107 & 105 & 101 & 1.059 & 1.040 & - & 91 & 94 & - & 0.968 & - & 64 & 67 & - & 0.955 \\
\hline $5 *$ & $\because \because \because \because$ & $\begin{array}{c}\text { Cellulose } \\
\text { Fibre }\end{array}$ & 110 & 109 & 108 & 1.019 & 1.009 & - & 101 & 103 & - & 0.981 & - & 64 & 70 & - & 0.914 \\
\hline $6^{*}$ & \begin{tabular}{|llllll} 
& $\cdots$ & & & \\
& & & & & \\
& & & & \\
\end{tabular} & $\begin{array}{l}\text { Rock } \\
\text { Fibre }\end{array}$ & $136^{\#}$ & 154 & 155 & - & 0.994 & - & 137 & 138 & - & 0.993 & - & 99 & 105 & - & 0.943 \\
\hline $7 *$ & 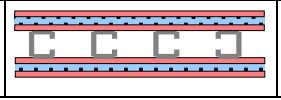 & $\begin{array}{c}\text { Cellulose } \\
\text { Fibre }\end{array}$ & 124 & 129 & 130 & 0.954 & 0.992 & - & 119 & 119 & - & 1.000 & - & 87 & 93 & - & 0.935 \\
\hline \multicolumn{6}{|c|}{ Mean } & $\begin{array}{l}0.998 \\
0.046\end{array}$ & $\begin{array}{l}1.003 \\
0.029\end{array}$ & & & & $\begin{array}{l}0.994 \\
0.030\end{array}$ & $\begin{array}{l}0.984 \\
0.016\end{array}$ & & & & - & $\begin{array}{l}0.908 \\
0.052\end{array}$ \\
\hline
\end{tabular}

Tests 1 - 3 : conducted by Gunalan [11]; Tests $1^{*}$ - 7* : conducted by Kolarkar [10]; (\# ) - Earlier Failure Time due to Lack of Thermal Expansion; (U) - Uniform Temperature Method; (NU) - Non-uniform Temperature Method; Load ratio is 0.2 for Tests 1 and $1^{*}-7^{*}$; Load ratio is 0.4 for Tests 2 and 3. 
Table 9: Failure Times Predicted by the Proposed Fire Design Rules Using Eurocode 3 Part 1.3 [17]

\begin{tabular}{|c|c|c|c|c|c|c|c|c|c|c|c|c|c|c|c|c|c|}
\hline \multirow{3}{*}{ Test } & \multirow{3}{*}{ Configuration } & \multirow{3}{*}{ Insulation } & \multicolumn{5}{|c|}{ Load Ratio $=0.2$} & \multicolumn{5}{|c|}{ Load Ratio $=0.4$} & \multicolumn{5}{|c|}{ Load Ratio $=0.7$} \\
\hline & & & \multicolumn{3}{|c|}{$\begin{array}{l}\text { Failure Time } \\
\text { (min.) }\end{array}$} & \multicolumn{2}{|c|}{ Ratio } & \multicolumn{3}{|c|}{$\begin{array}{l}\text { Failure Time } \\
\text { (min.) }\end{array}$} & \multicolumn{2}{|c|}{ Ratio } & \multicolumn{3}{|c|}{$\begin{array}{l}\text { Failure Time } \\
\text { (min.) }\end{array}$} & \multicolumn{2}{|c|}{ Ratio } \\
\hline & & & Test & FEA & Prop. & $\mathrm{T} / \mathrm{P}$ & $\mathrm{F} / \mathrm{P}$ & Test & FEA & Prop. & $\mathrm{T} / \mathrm{P}$ & $\mathrm{F} / \mathrm{P}$ & Test & FEA & Prop. & $\mathrm{T} / \mathrm{P}$ & $\mathrm{F} / \mathrm{P}$ \\
\hline 1 & 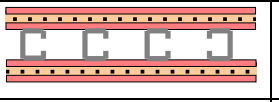 & $\begin{array}{l}\text { Glass } \\
\text { Fibre }\end{array}$ & 118 & 115 & 115 & 1.026 & 1.000 & - & 109 & 107 & - & 1.019 & - & 72 & 82 & - & 0.878 \\
\hline 2 & 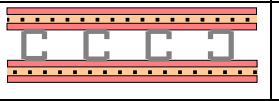 & $\begin{array}{l}\text { Glass } \\
\text { Fibre }\end{array}$ & - & 116 & 115 & - & 1.009 & 108 & 110 & 109 & 0.991 & 1.009 & - & 85 & 92 & - & 0.924 \\
\hline 3 & 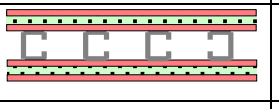 & $\begin{array}{l}\text { Rock } \\
\text { Fibre }\end{array}$ & - & 143 & 137 & - & 1.044 & 134 & 131 & 128 & 1.047 & 1.023 & - & 95 & 101 & - & 0.941 \\
\hline $1^{*}$ & $\begin{array}{llll} & 5 & 5 & \\
\end{array}$ & None & 53 & 53 & 53 & 1.000 & 1.000 & - & 42 & 41 & - & 1.024 & - & 20 & 25 & - & 0.800 \\
\hline $2 *$ & \begin{tabular}{|llllll} 
& \multicolumn{1}{c}{} & $\mathrm{C}$ & $\mathrm{C}$ & $\mathrm{C}$ & $\mathrm{U}$ \\
\end{tabular} & None & 111 & 115 & 114 & 0.974 & 1.009 & - & 107 & 105 & - & 1.019 & - & 63 & 73 & - & 0.863 \\
\hline $3 *$ & - & $\begin{array}{l}\text { Glass } \\
\text { Fibre }\end{array}$ & 101 & 100 & 98 & 1.031 & 1.020 & - & 88 & 89 & - & 0.989 & - & 62 & 67 & - & 0.925 \\
\hline $4^{*}$ & मаara: & $\begin{array}{l}\text { Rock } \\
\text { Fibre } \\
\end{array}$ & 107 & 105 & 101 & 1.059 & 1.040 & - & 91 & 91 & - & 1.000 & - & 64 & 68 & - & 0.941 \\
\hline $5^{*}$ & a $-\cdots$ & $\begin{array}{l}\text { Cellulose } \\
\text { Fibre }\end{array}$ & 110 & 109 & 108 & 1.019 & 1.009 & - & 101 & 102 & - & 0.990 & - & 64 & 70 & - & 0.914 \\
\hline $6^{*}$ & 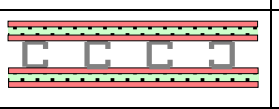 & $\begin{array}{l}\text { Rock } \\
\text { Fibre }\end{array}$ & $136^{\#}$ & 154 & 153 & - & 1.007 & - & 137 & 133 & - & 1.030 & - & 99 & 105 & - & 0.943 \\
\hline $7 *$ & 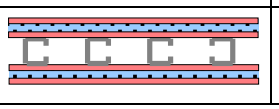 & $\begin{array}{l}\text { Cellulose } \\
\text { Fibre }\end{array}$ & 124 & 129 & 128 & 0.969 & 1.008 & - & 119 & 116 & - & 1.026 & - & 87 & 93 & - & 0.935 \\
\hline & & $\begin{array}{l}\text { Mean } \\
\text { COV }\end{array}$ & & & & $\begin{array}{l}1.011 \\
0.032 \\
\end{array}$ & $\begin{array}{l}1.014 \\
0.015 \\
\end{array}$ & & & & $\begin{array}{l}1.019 \\
0.039\end{array}$ & $\begin{array}{l}1.013 \\
0.015\end{array}$ & & & & - & $\begin{array}{l}0.906 \\
0.051\end{array}$ \\
\hline
\end{tabular}

Tests 1 - 3 : conducted by Gunalan [11]; Tests $1 *$ - 7* : conducted by Kolarkar [10]; ( \# ) - Earlier Failure Time due to Lack of Thermal Expansion; (U) - Uniform Temperature Method; (NU) - Non-uniform Temperature Method; Load ratio is 0.2 for Tests 1 and $1^{*}$ - 7*; Load ratio is 0.4 for Tests 2 and 3. 
Table 10: Predicted Failure Times for 1.15 mm G250 Steel Stud Walls

\begin{tabular}{|c|c|c|c|c|c|c|c|c|c|c|c|}
\hline \multirow{3}{*}{ Index } & \multirow{3}{*}{ Configuration } & \multirow{3}{*}{ Insulation } & \multicolumn{9}{|c|}{ Failure Time (min.) } \\
\hline & & & \multicolumn{3}{|c|}{ Load Ratio 0.2} & \multicolumn{3}{|c|}{ Load Ratio 0.4} & \multicolumn{3}{|c|}{ Load Ratio 0.7} \\
\hline & & & FEA & AS & EC3 & FEA & AS & EC3 & FEA & AS & EC3 \\
\hline $1 \times 1$ & $\begin{array}{lllll} & 1 & 0 & 1 & 1\end{array}$ & None & 56 & 58 & 58 & 39 & 38 & 38 & 25 & 22 & 22 \\
\hline $2 \times 2$ & 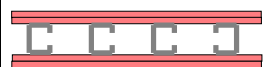 & None & 120 & 118 & 118 & 93 & 97 & 98 & 71 & 64 & 64 \\
\hline CI-GF & a & $\begin{array}{l}\text { Glass } \\
\text { Fibre }\end{array}$ & 104 & 101 & 99 & 88 & 83 & 81 & 66 & 64 & 64 \\
\hline CI-RF & $a \because \cdots \cdots$ & $\begin{array}{l}\text { Rock } \\
\text { Fibre }\end{array}$ & 109 & 105 & 102 & 91 & 86 & 84 & 67 & 65 & 65 \\
\hline CI-CF & $\because \because \because \cdots \cdots$ & $\begin{array}{l}\text { Cellulose } \\
\text { Fibre }\end{array}$ & 111 & 108 & 107 & 95 & 90 & 87 & 68 & 65 & 66 \\
\hline CP-GF & 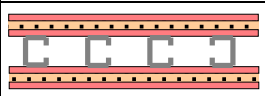 & $\begin{array}{l}\text { Glass } \\
\text { Fibre }\end{array}$ & 118 & 117 & 117 & 102 & 104 & 104 & 84 & 78 & 78 \\
\hline CP-RF & 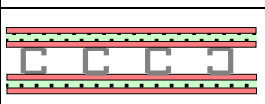 & $\begin{array}{l}\text { Rock } \\
\text { Fibre }\end{array}$ & 148 & 148 & 149 & 122 & 124 & 125 & 102 & 96 & 96 \\
\hline CP-CF & 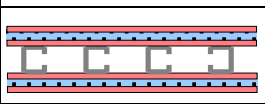 & $\begin{array}{l}\text { Cellulose } \\
\text { Fibre }\end{array}$ & 133 & 132 & 133 & 110 & 111 & 112 & 92 & 87 & 88 \\
\hline
\end{tabular}

AS - Proposed fire design rules using AS/NZS 4600 [15];

EC3 - Proposed fire design rules using Eurocode 3 Part 1.3 [17]. 
Table 11: Predicted Failure Times for 1.95 mm G250 Steel Stud Walls

\begin{tabular}{|c|c|c|c|c|c|c|c|c|c|c|c|}
\hline \multirow{3}{*}{ Index } & \multirow{3}{*}{ Configuration } & \multirow{3}{*}{ Insulation } & \multicolumn{9}{|c|}{ Failure Time (min.) } \\
\hline & & & \multicolumn{3}{|c|}{ Load Ratio 0.2} & \multicolumn{3}{|c|}{ Load Ratio 0.4} & \multicolumn{3}{|c|}{ Load Ratio 0.7} \\
\hline & & & FEA & AS & EC3 & FEA & AS & EC3 & FEA & AS & EC3 \\
\hline $1 \times 1$ & {$\left[\begin{array}{llll} & {[} & {[} & 1\end{array}\right]$} & None & 52 & 56 & 57 & 34 & 36 & 36 & 19 & 20 & 21 \\
\hline $2 \times 2$ & 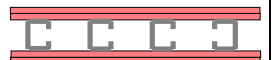 & None & 117 & 118 & 117 & 83 & 94 & 96 & 51 & 59 & 61 \\
\hline CI-GF & $\because \because \cdots$ & $\begin{array}{l}\text { Glass } \\
\text { Fibre }\end{array}$ & 99 & 100 & 98 & 80 & 80 & 80 & 59 & 62 & 63 \\
\hline CI-RF & arar & $\begin{array}{l}\text { Rock } \\
\text { Fibre }\end{array}$ & 104 & 103 & 101 & 82 & 82 & 82 & 59 & 62 & 63 \\
\hline CI-CF & $\therefore \because \cdots$ & $\begin{array}{l}\text { Cellulose } \\
\text { Fibre }\end{array}$ & 108 & 108 & 106 & 85 & 86 & 86 & 59 & 63 & 64 \\
\hline CP-GF & $\begin{array}{lll}\ldots \ldots \ldots \\
\end{array}$ & $\begin{array}{l}\text { Glass } \\
\text { Fibre }\end{array}$ & 114 & 116 & 116 & 96 & 102 & 103 & 60 & 73 & 75 \\
\hline CP-RF & 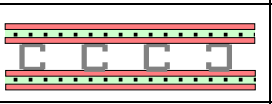 & $\begin{array}{l}\text { Rock } \\
\text { Fibre }\end{array}$ & 141 & 147 & 148 & 115 & 121 & 123 & 84 & 92 & 94 \\
\hline $\mathrm{CP}-\mathrm{CF}$ & $\begin{array}{lll}\ldots \ldots \ldots \\
\end{array}$ & $\begin{array}{l}\text { Cellulose } \\
\text { Fibre }\end{array}$ & 126 & 131 & 132 & 105 & 109 & 110 & 79 & 84 & 85 \\
\hline
\end{tabular}

AS - Proposed fire design rules using AS/NZS 4600 [15];

EC3 - Proposed fire design rules using Eurocode 3 Part 1.3 [17]. 


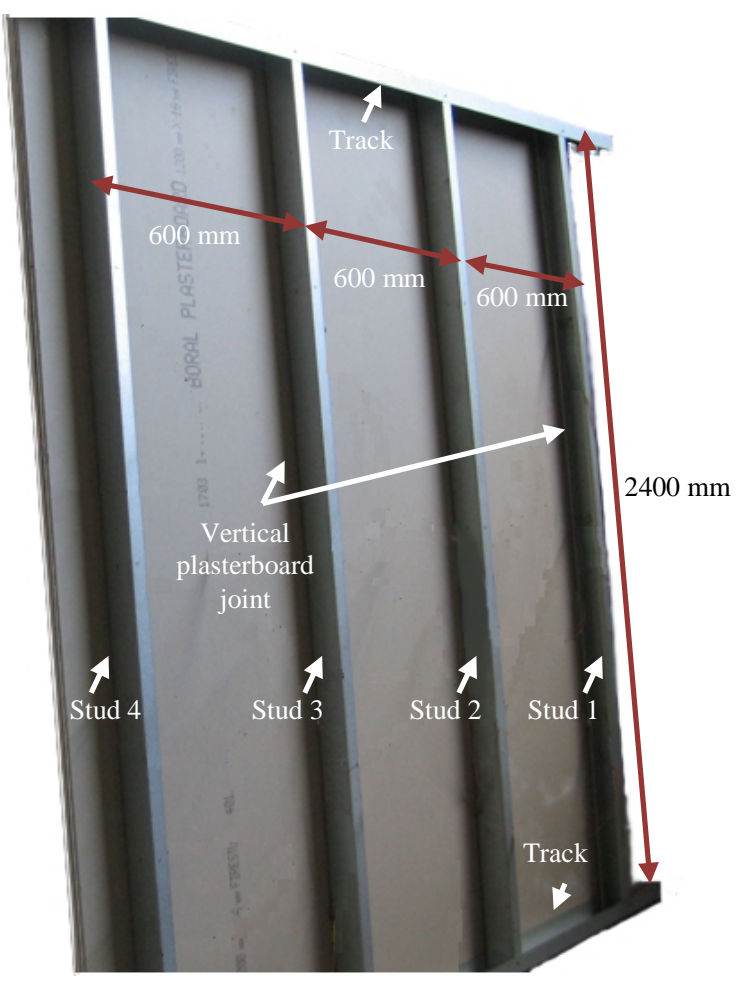

Figure 1: LSF Wall System 


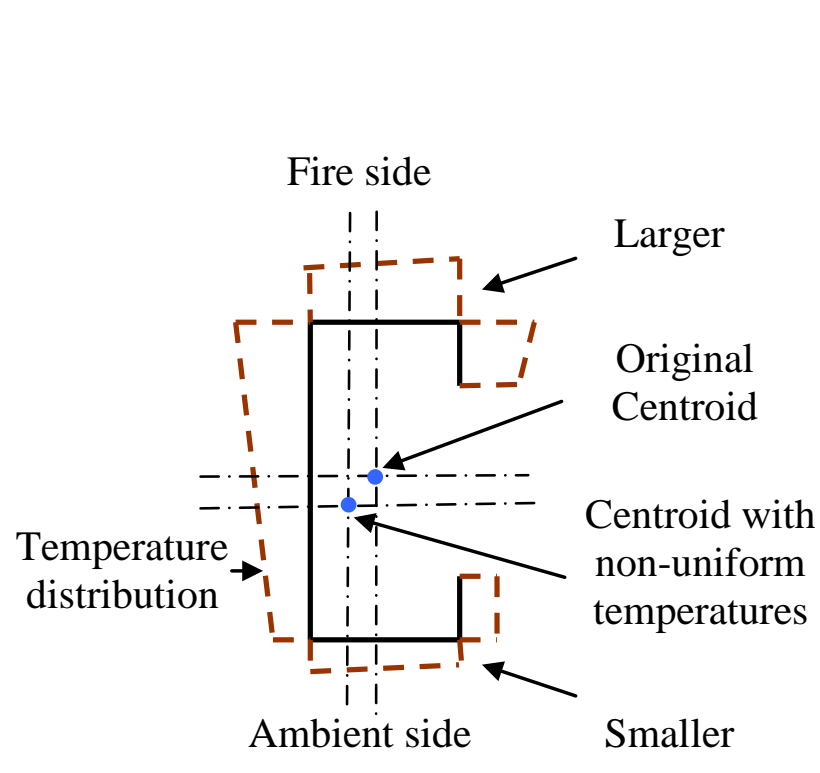

(a) Neutral axis shift $\left(e_{\Delta E}\right)$

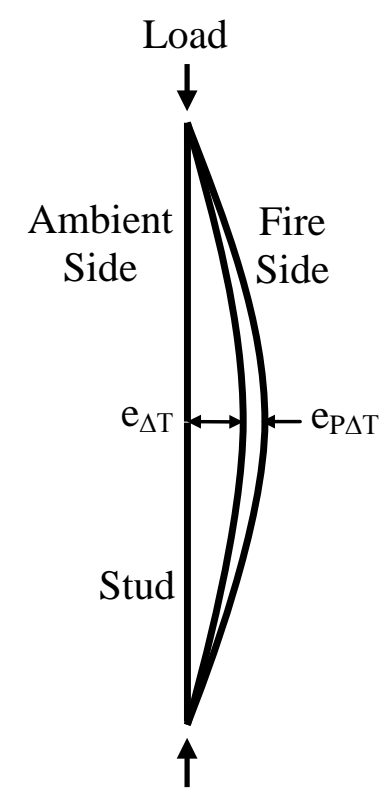

(b) Thermal bowing $\left(\mathrm{e}_{\Delta \mathrm{T}}\right)$ and magnification effects $\left(\mathrm{e}_{\mathrm{P} \Delta \mathrm{T}}\right)$
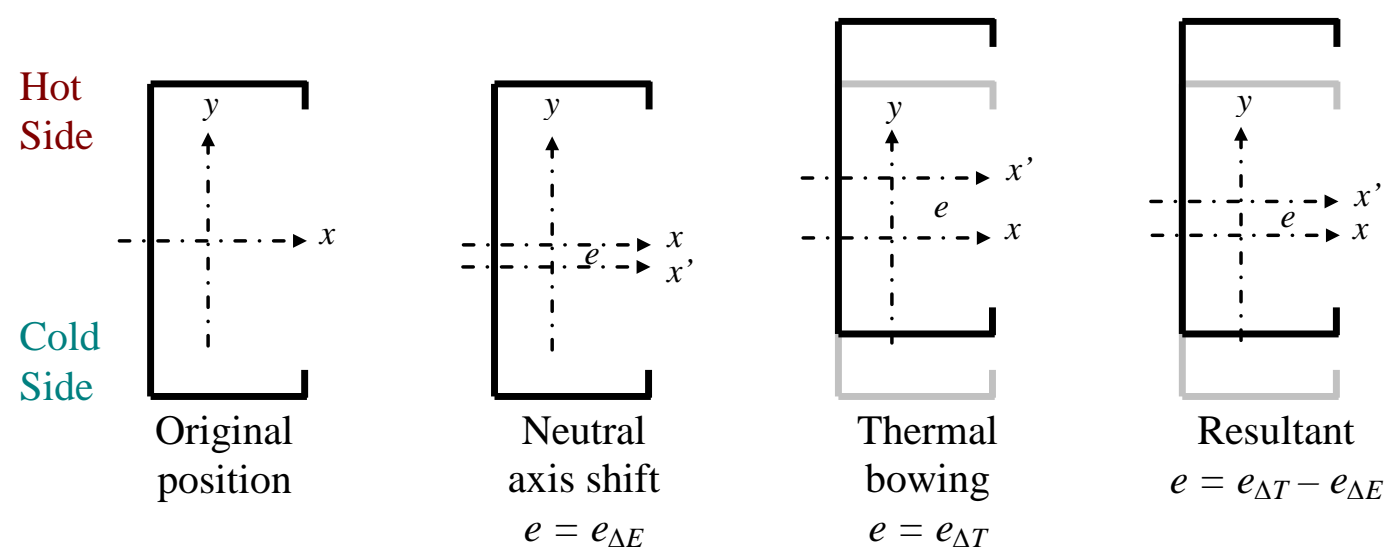

(c) Lateral deflections of LSF wall stud

Figure 2: Behaviour of LSF Wall Stud under Non-uniform Temperature Distribution 


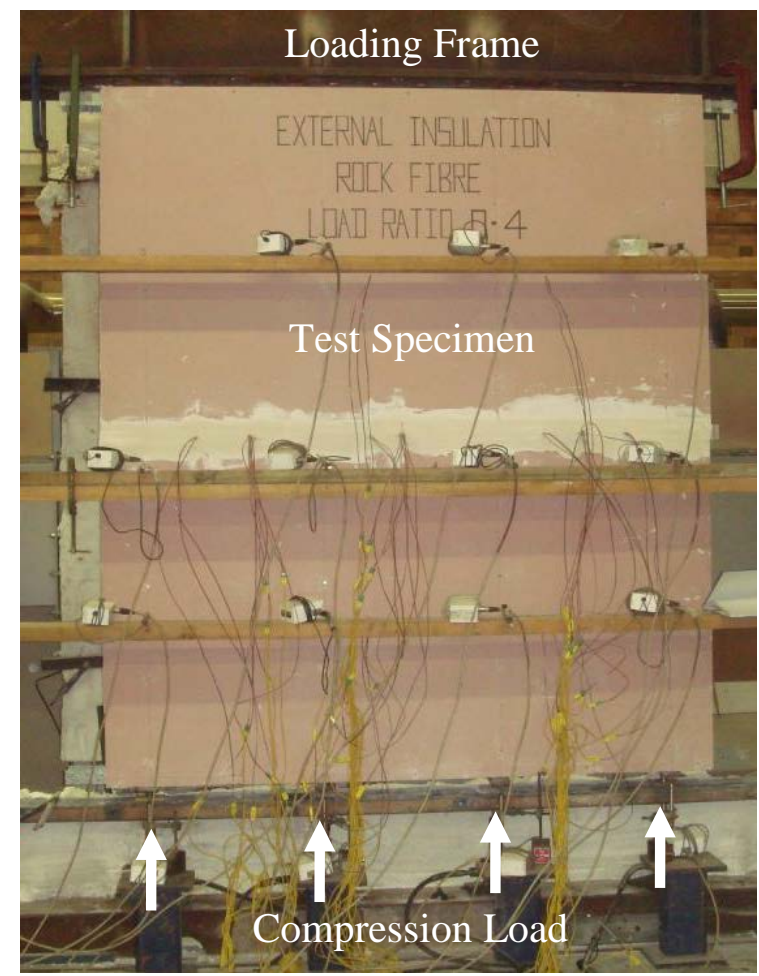

(a) Test Specimen before fire test ambient side

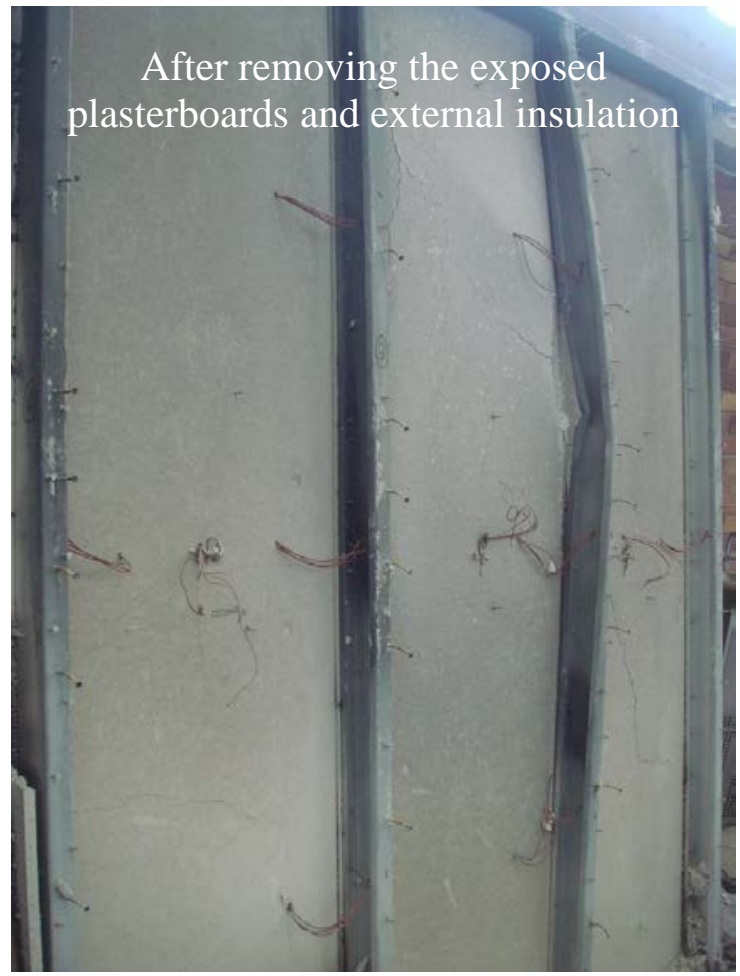

(b) Test Specimen after fire test fire side

Figure 3: Experimental Study 


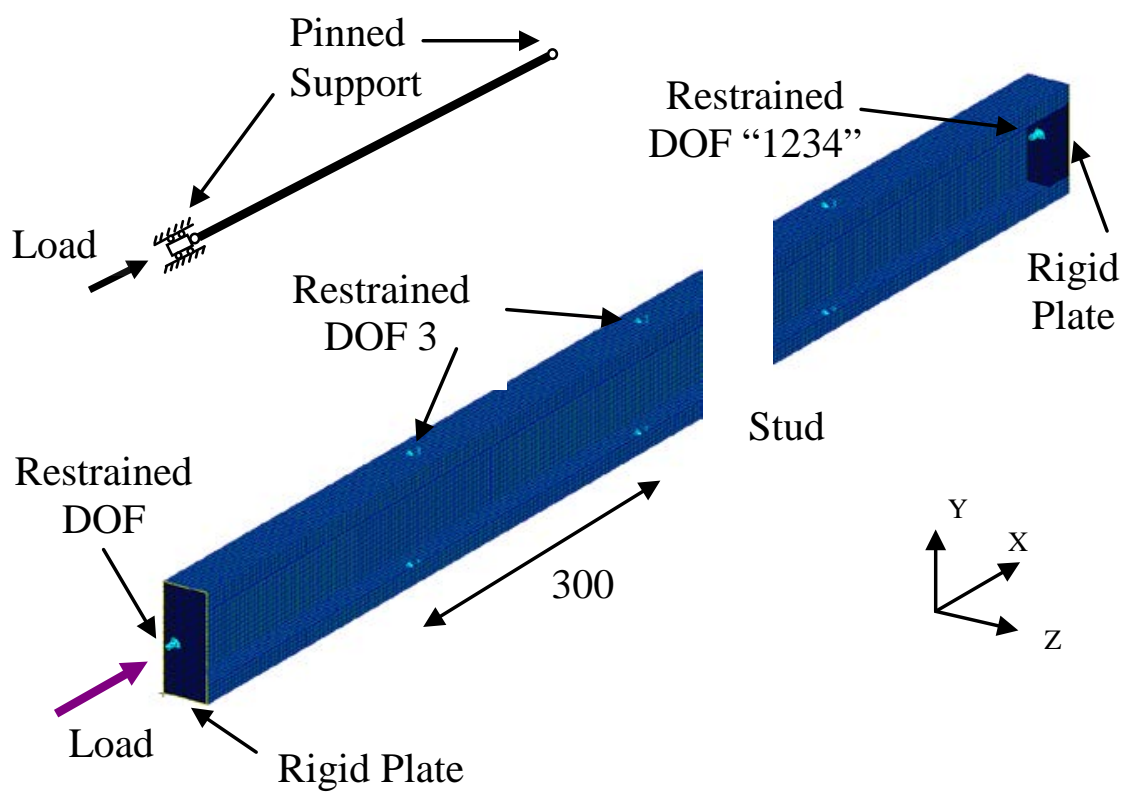

(a) Loading and boundary conditions

Patran 2008r1 01-Oct-10 14:04:59

Fringe: S3Temp, Step2,TotalTime=115.91_32. Deformation, Displacements, Magnitude, (NON-LAYERED)

Deform: S3Temp. Step2,TotalTime=115.91_32, Deformation. Displacements.

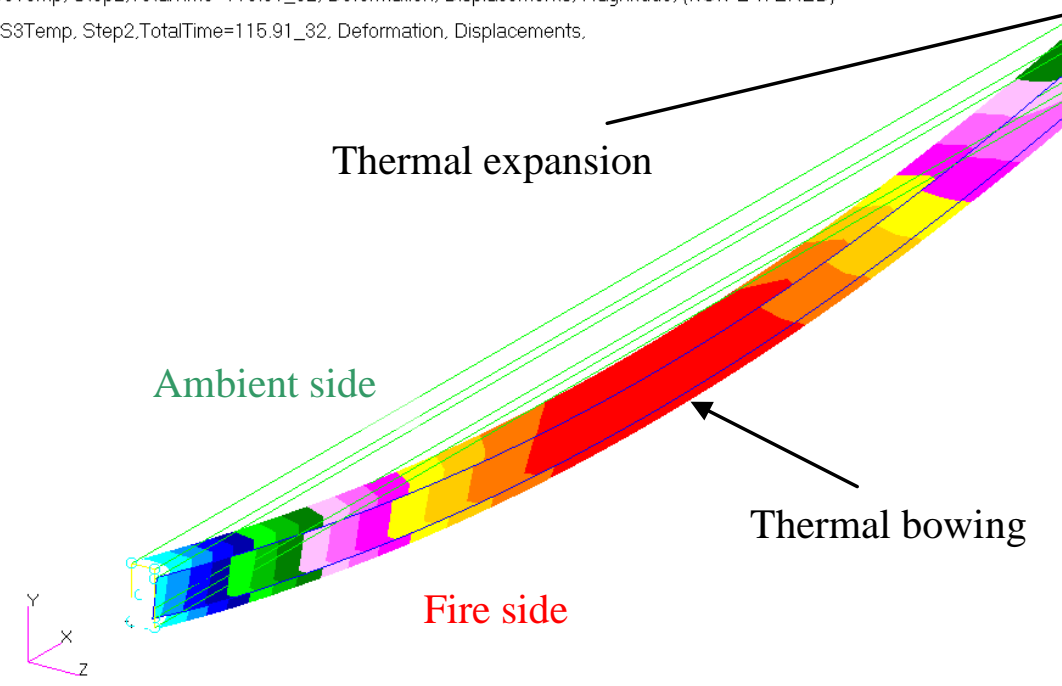

(b) Thermal bowing and expansion of stud

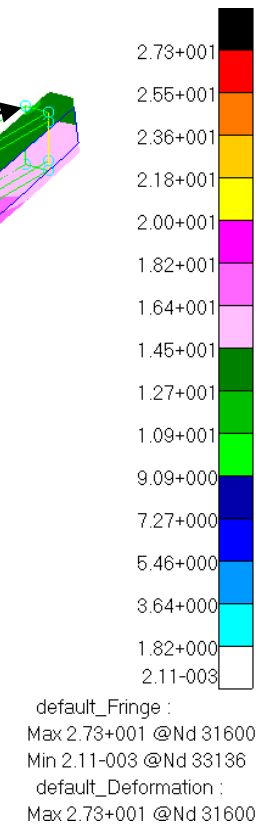

Figure 4: Numerical Study 


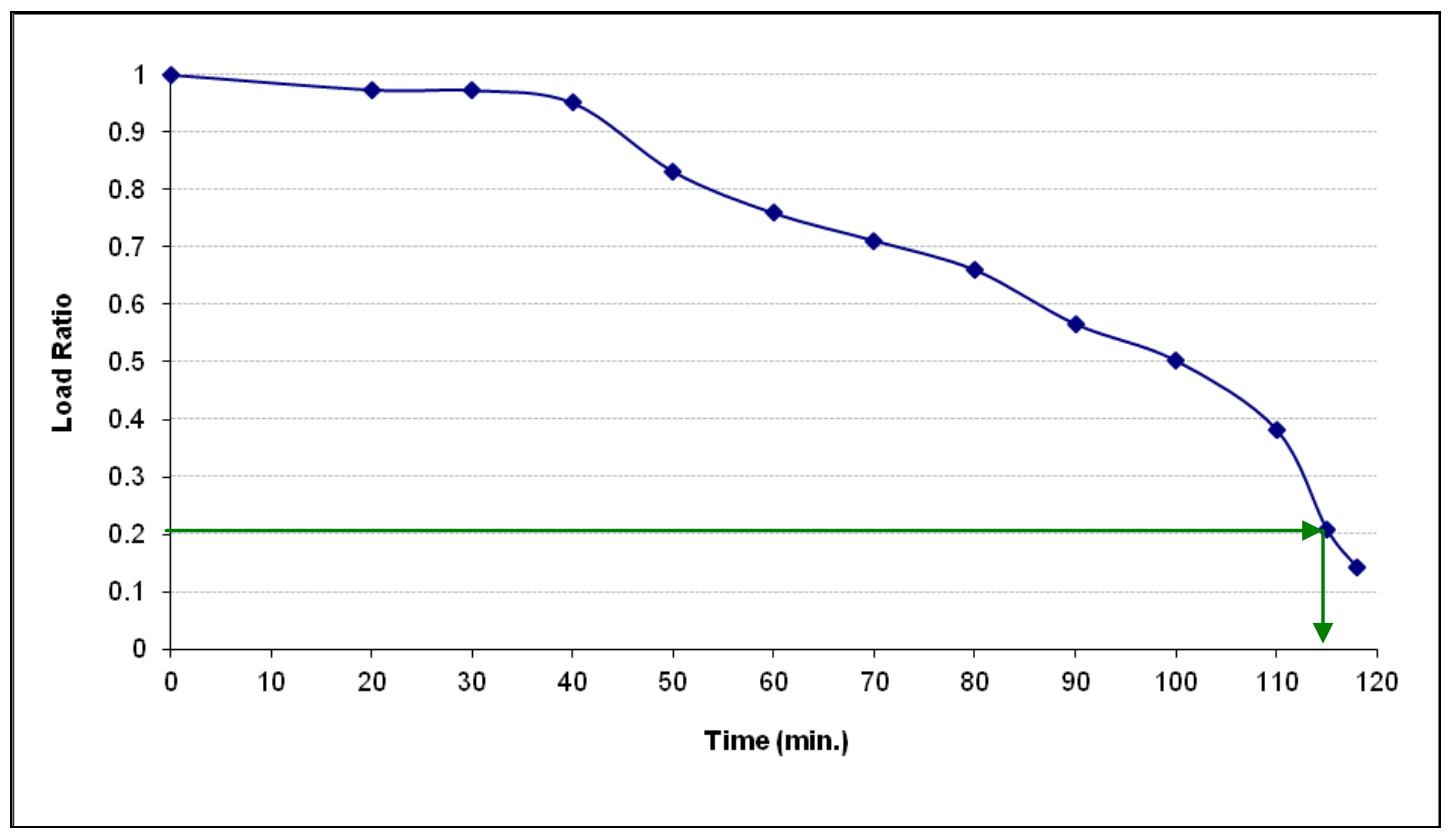

(a) Variation of load ratio with time

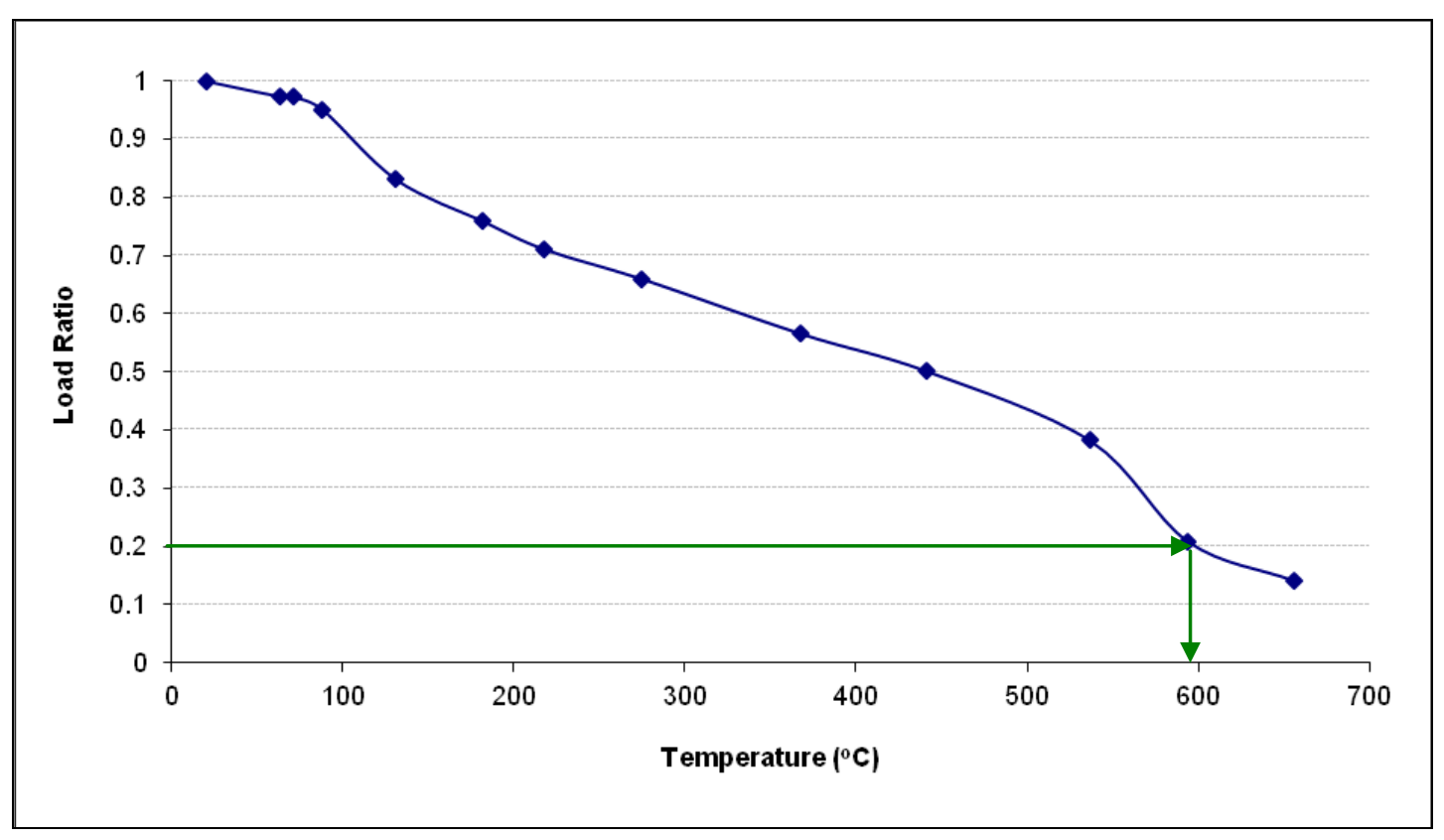

(b) Variation of load ratio with hot flange temperature

Figure 5: FEA Results for Stud 3 of Test 1 under Steady State Conditions 

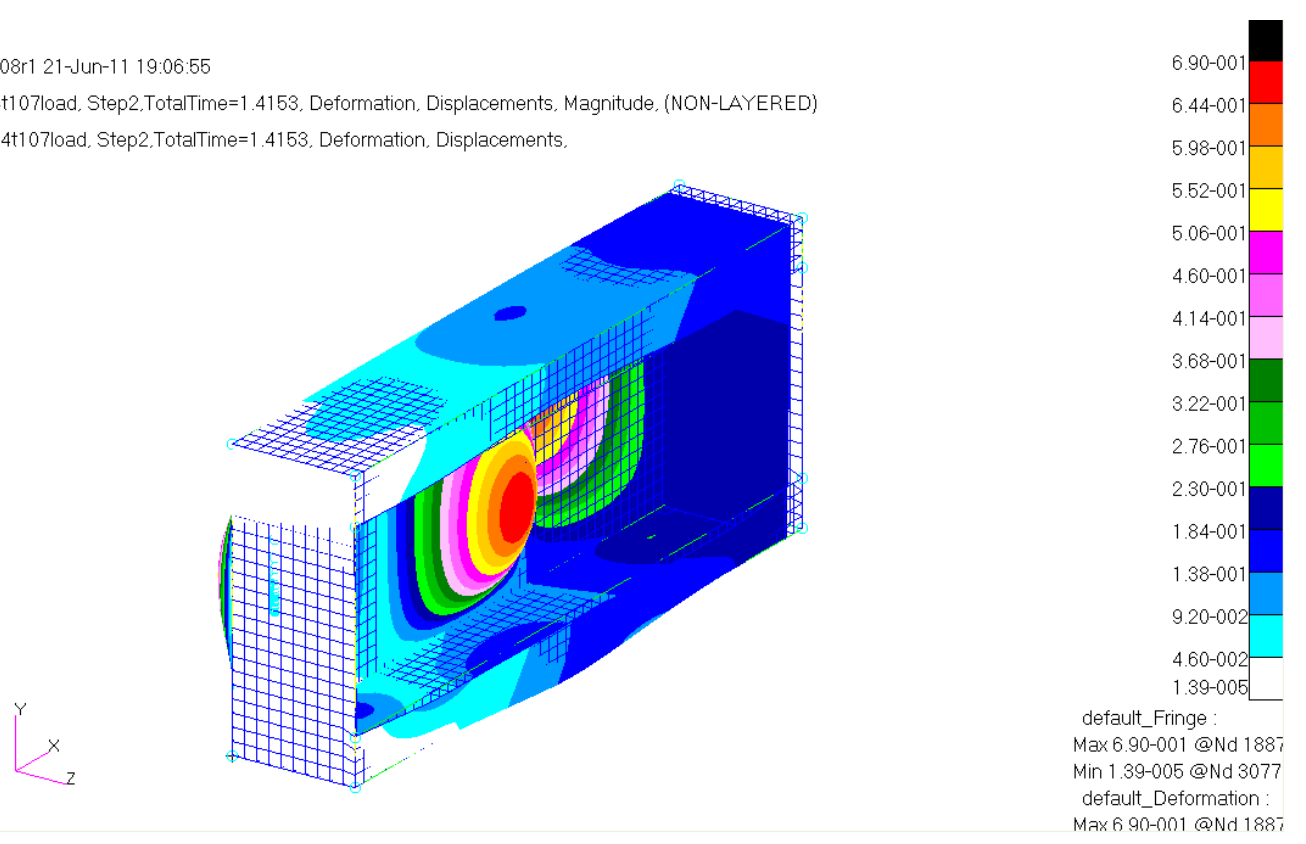

Figure 6: Failure Mode for Short LSF Wall Stud of Test 4* under Fire Conditions 
(a) Test 1

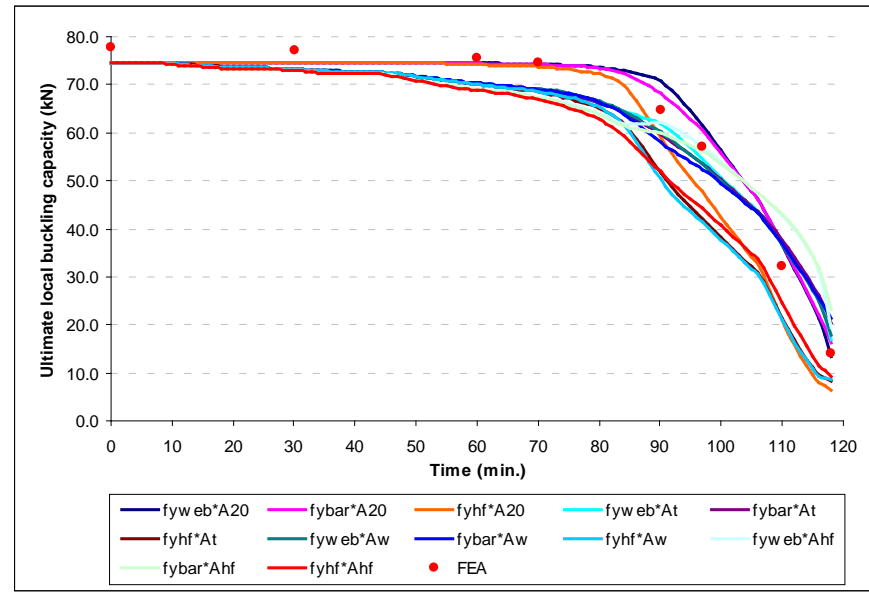

(b) Test 1*

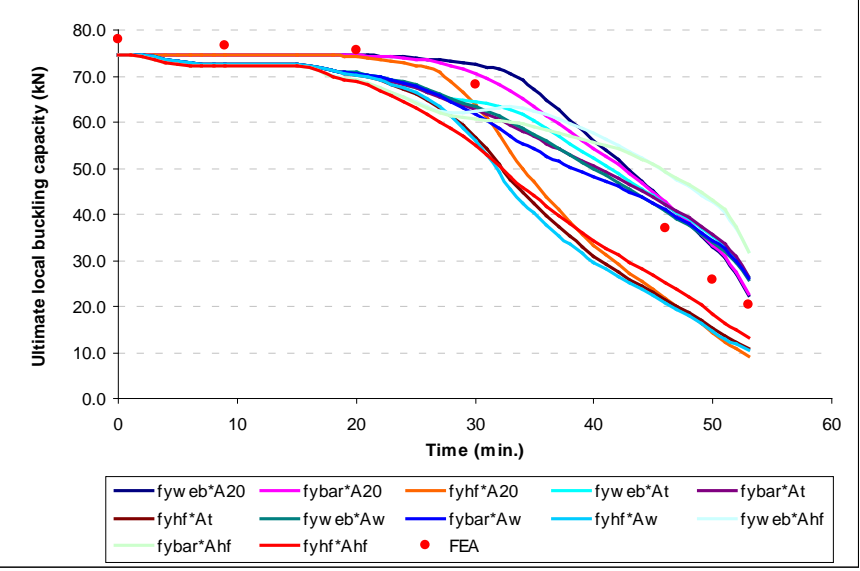

(c) Test 2*

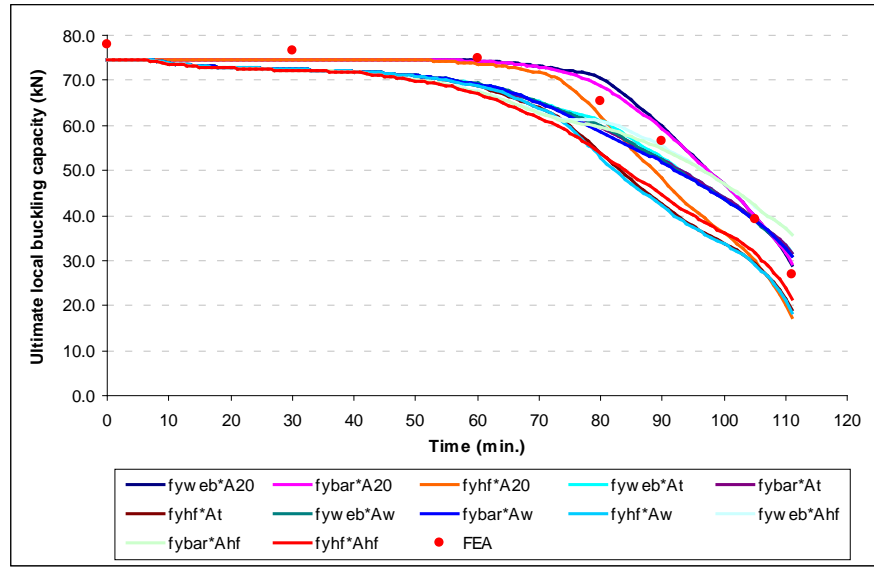

(d) Test 4*

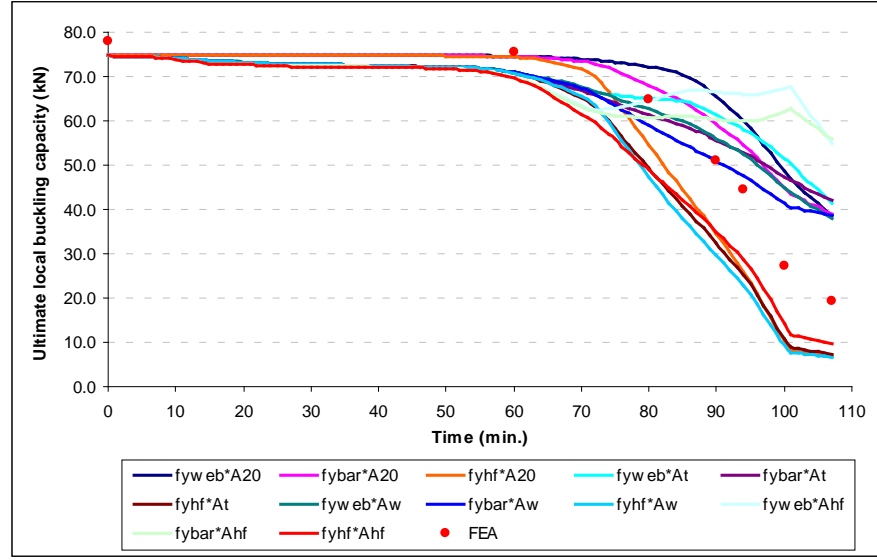

Figure 7: Variation of Ultimate Local Buckling Capacity with Time 


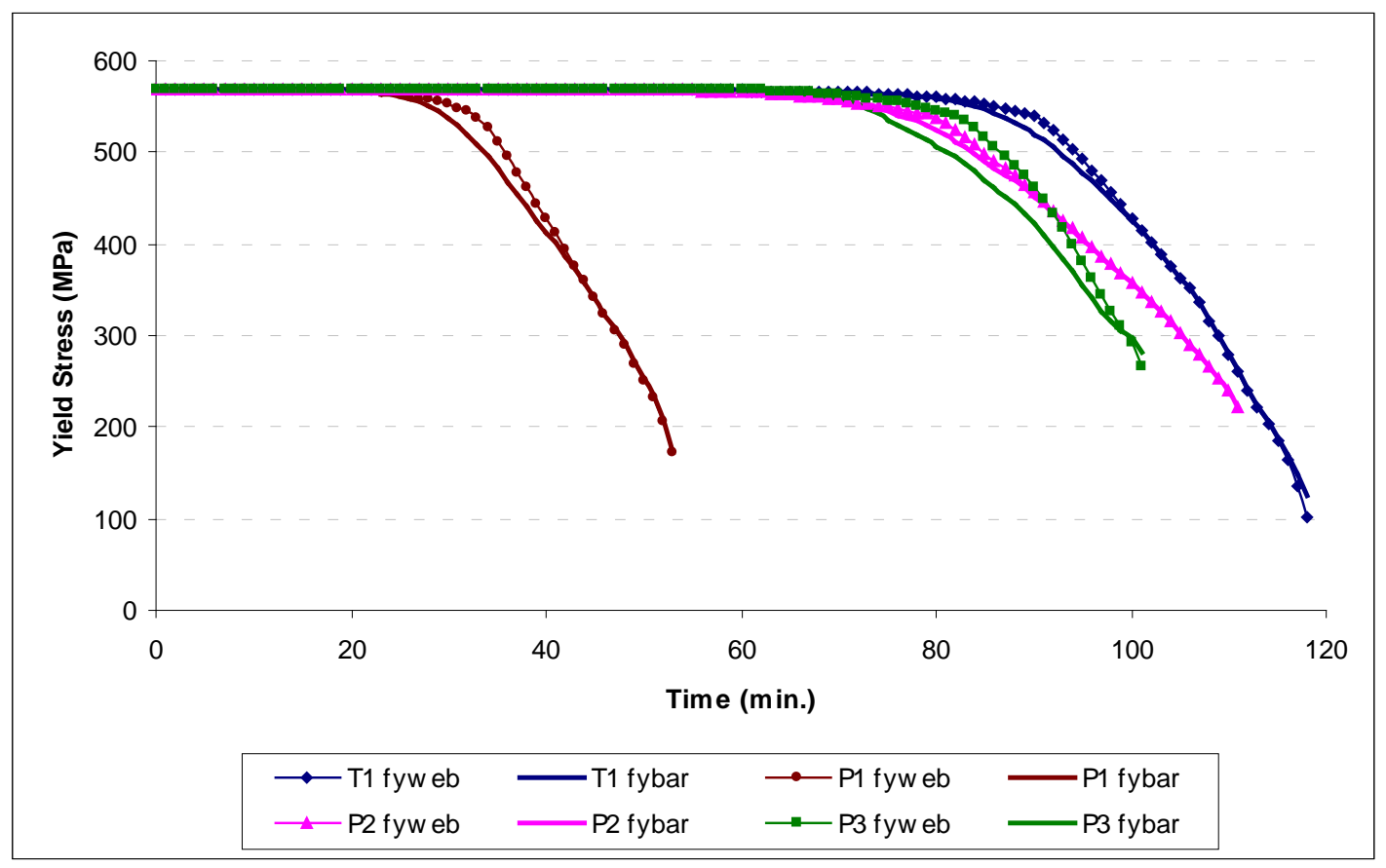

Figure 8: Variation of Yield Stress with Time 
(a) Test 1

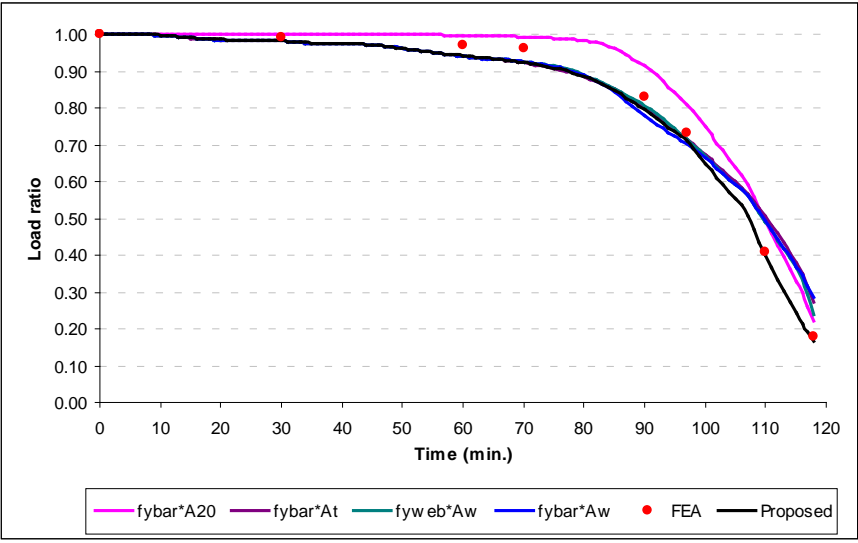

(b) Test 1*

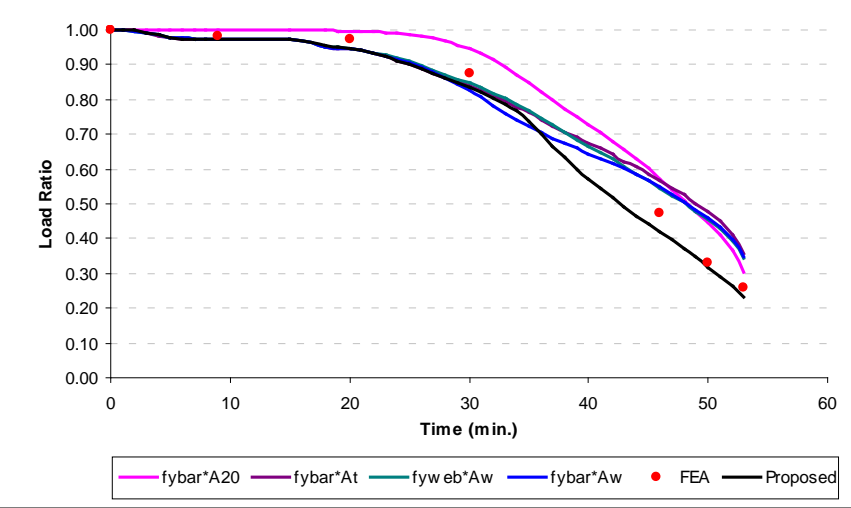

(c) Test 2*

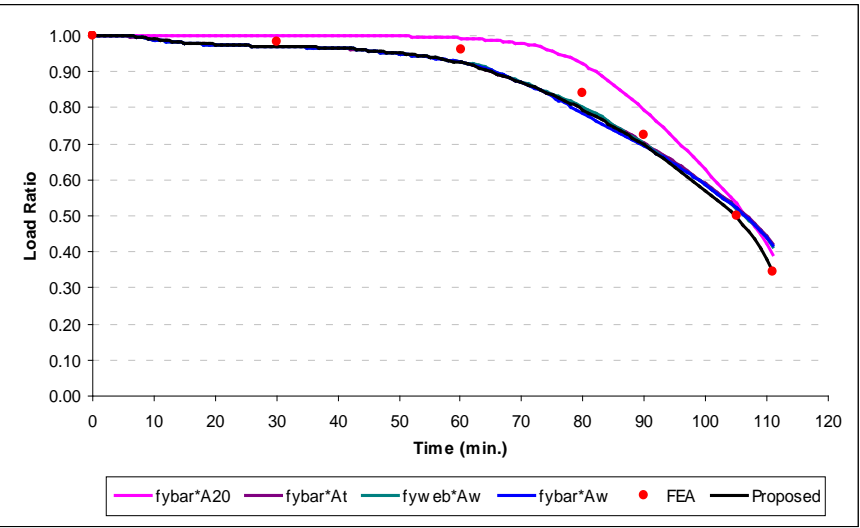

(d) Test 4*

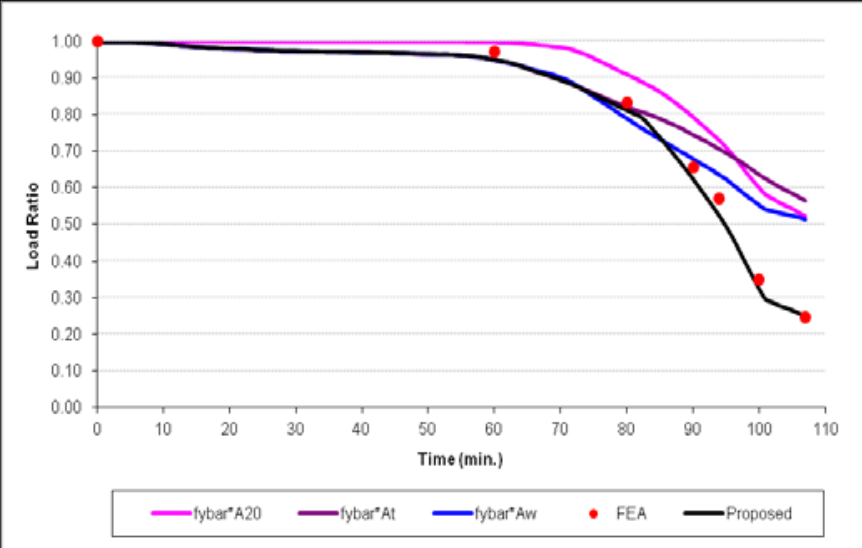

Figure 9: Variation of Load Ratio with Time 
Patran 2008r1 22-Jun-11 10:47:50

Fringe: p4t107load, Step2,TotalTime=1.4153, Stress, Components, von Mises, At SECTION_POINT_1

Deform: p4t107load, Step2,TotalTime=1.4153, Deformation, Displacements,
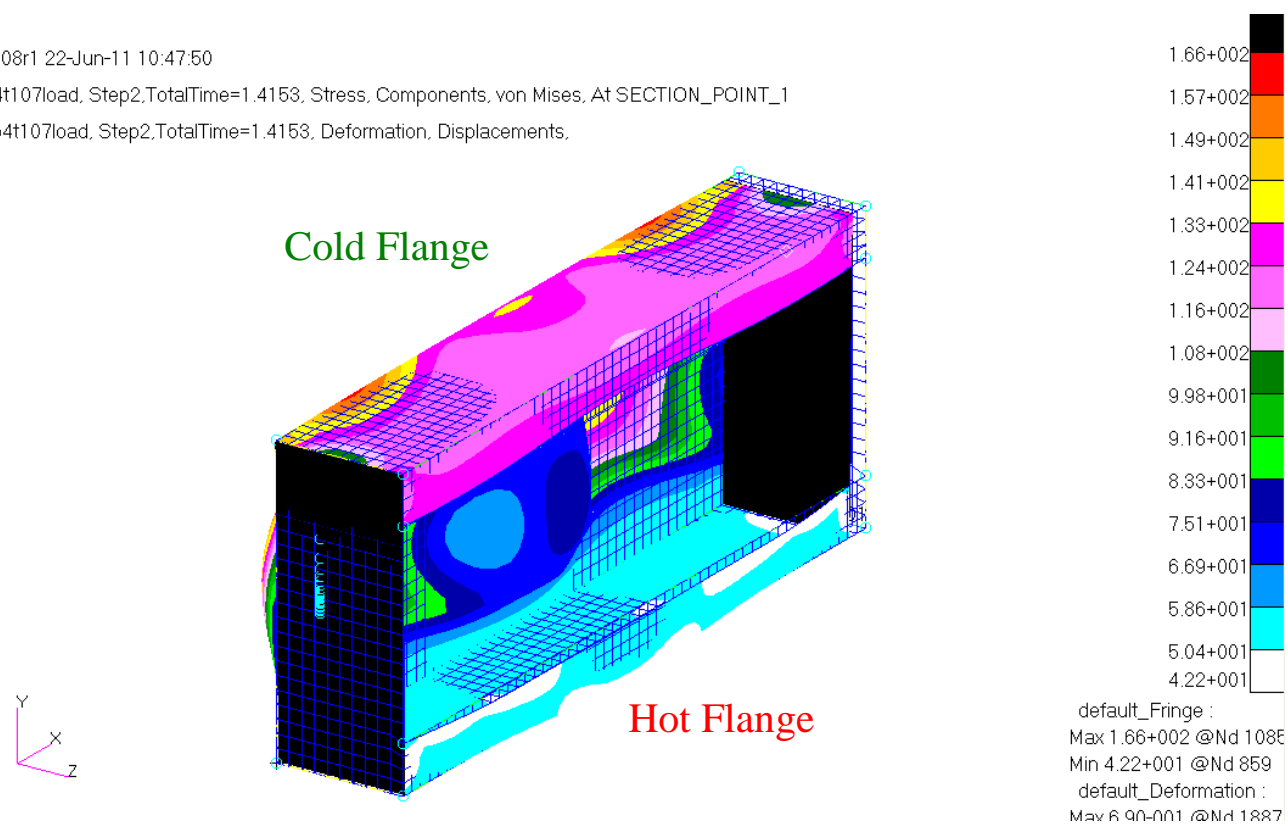

Figure 10: von Mises Stress Distribution at Failure for Short LSF Wall Stud of Test 4* under Fire Conditions 


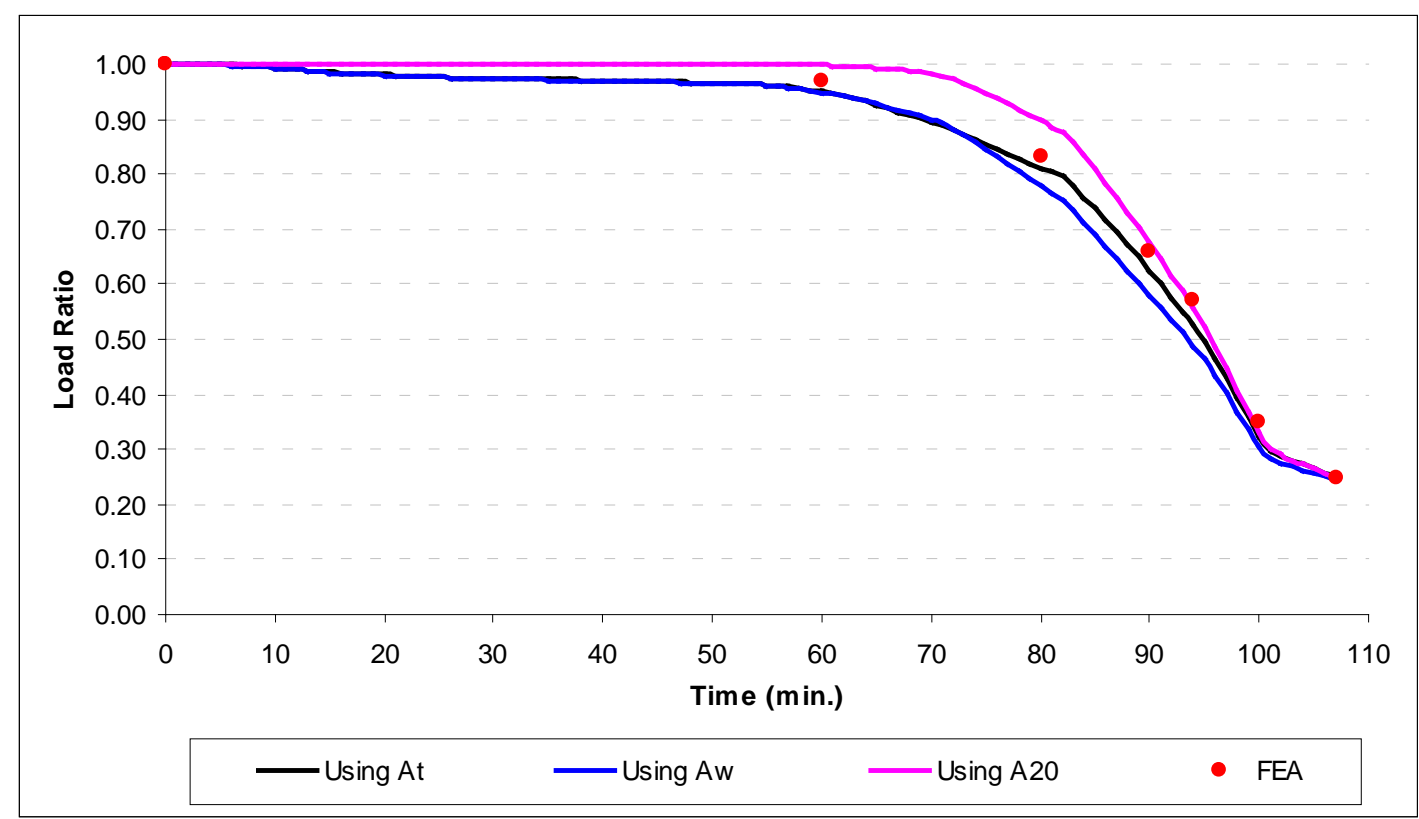

Figure 11: Proposed Method based on the Selected Options for Test 4* 


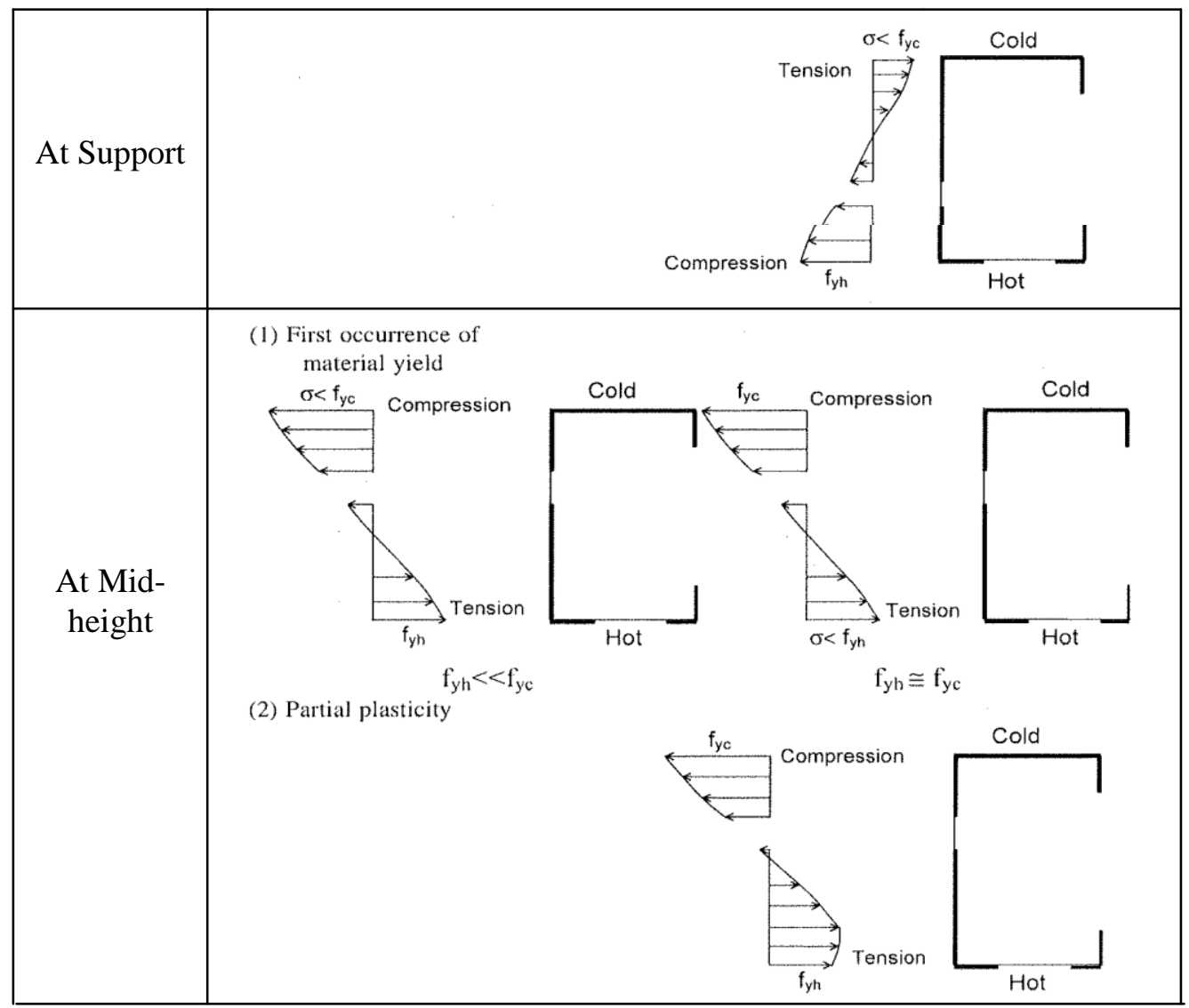

Figure 12: Stress Distributions for Section Moment Capacity Calculations [6,21] 
(a) Test 1

(b) Test 1*
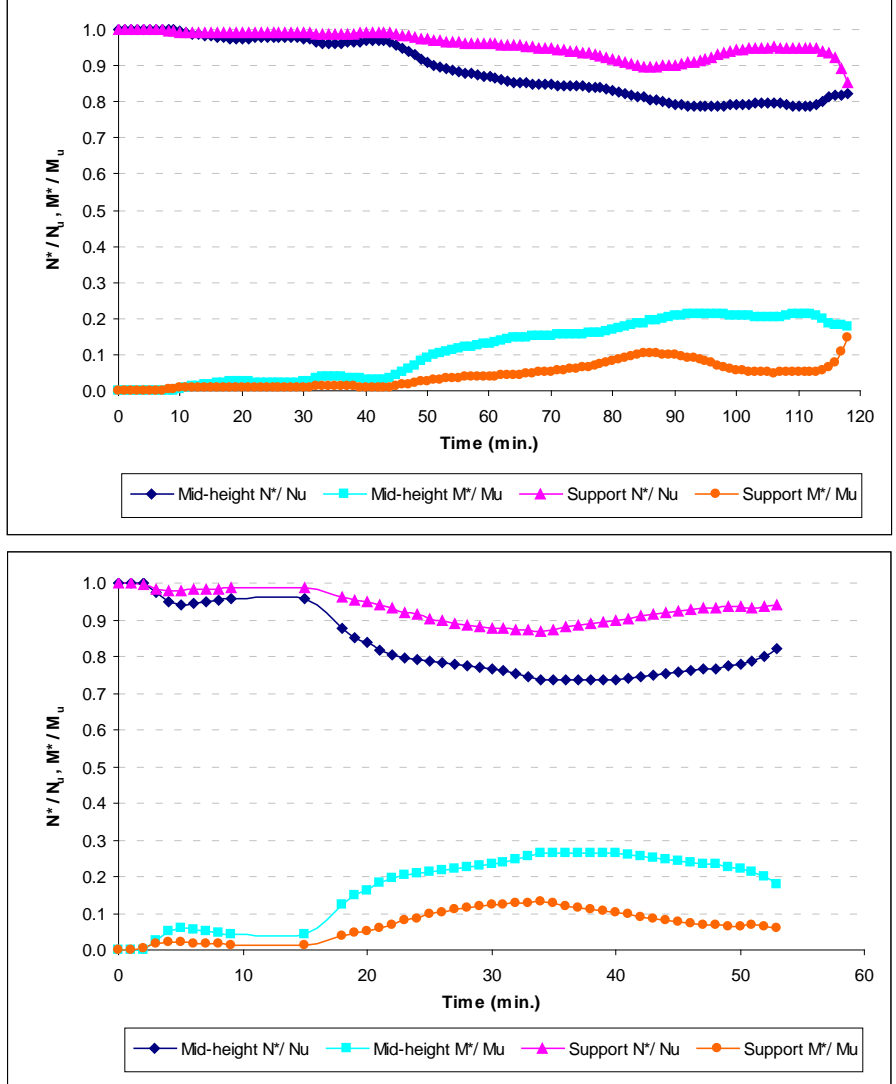

(c) Test 2*

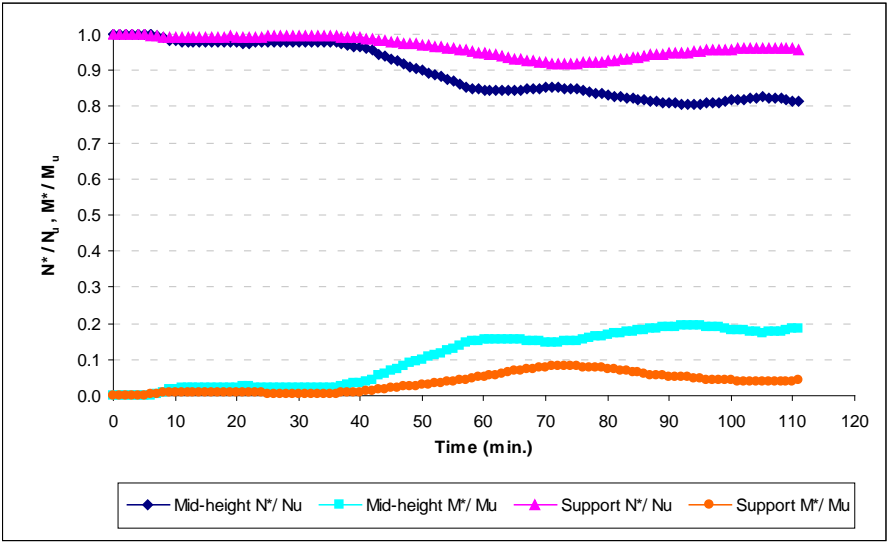

(d) Test 4*

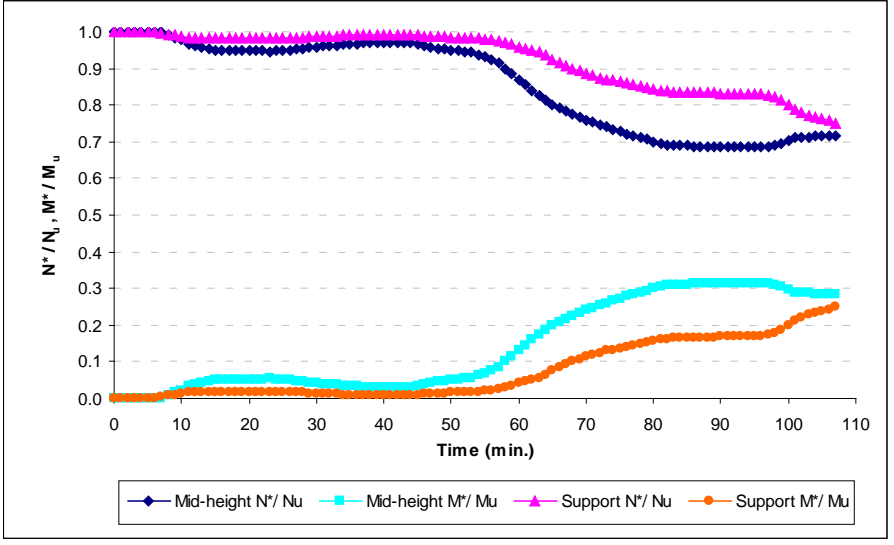

Figure 13: Interaction of Compression and Bending 
(a) Test 1

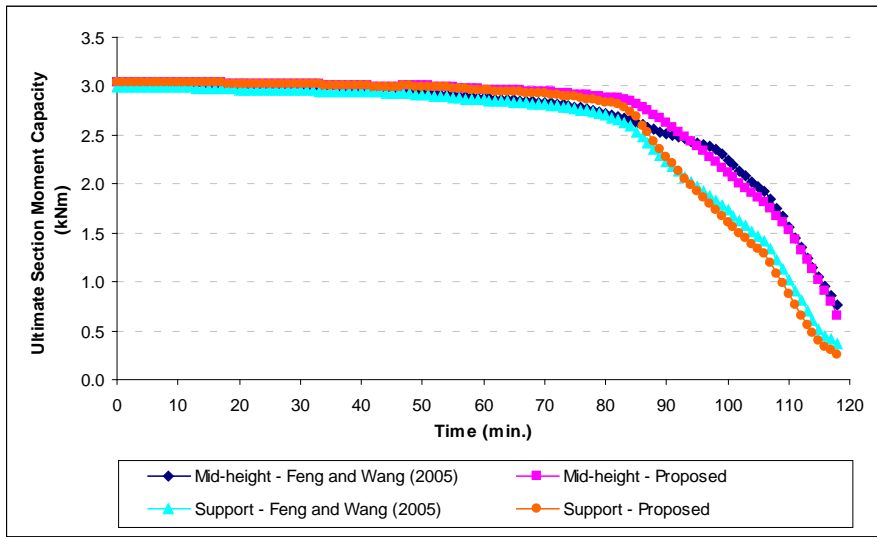

(b) Test $1^{*}$

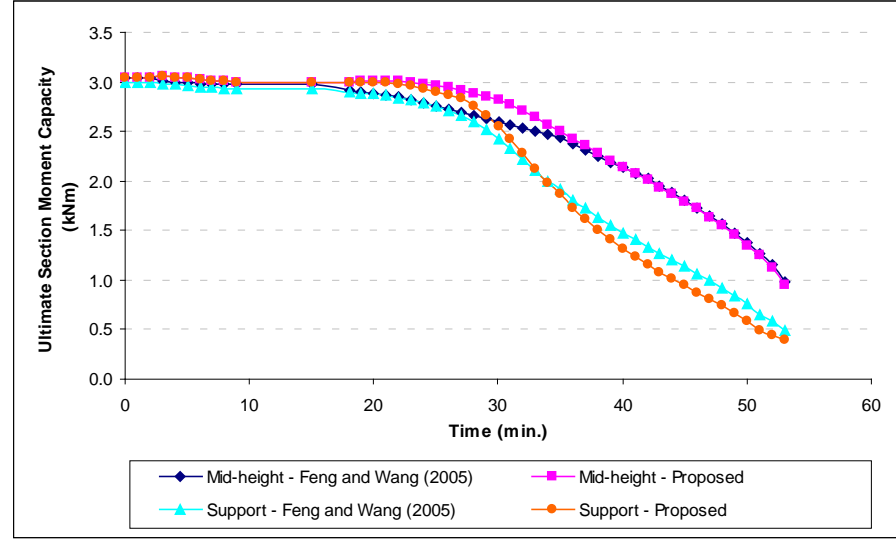

(c) Test 2*

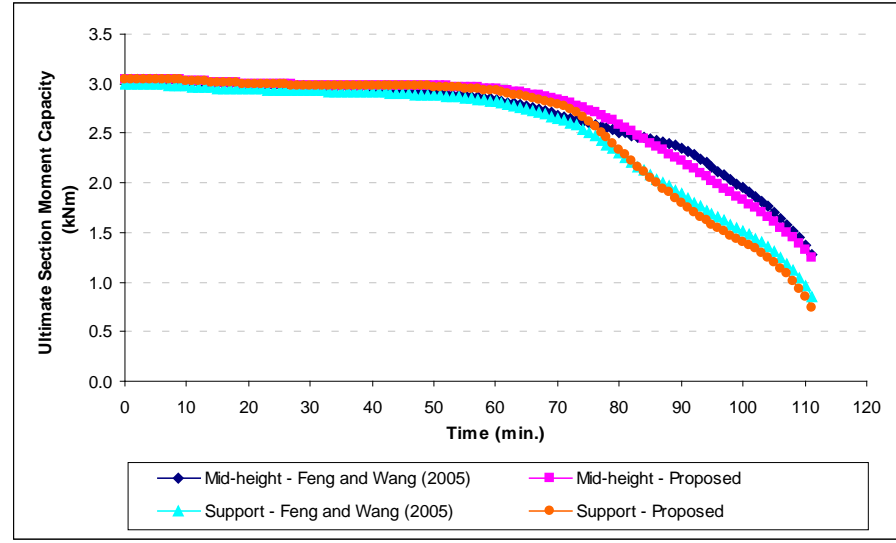

(d) Test 4*

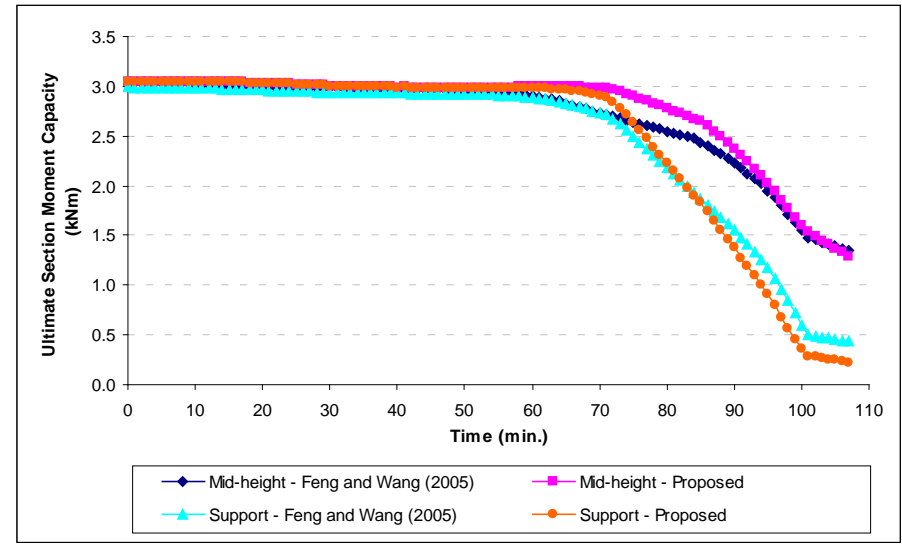

Figure 14: Variation of Section Moment Capacity with Time 
(a) Test 1

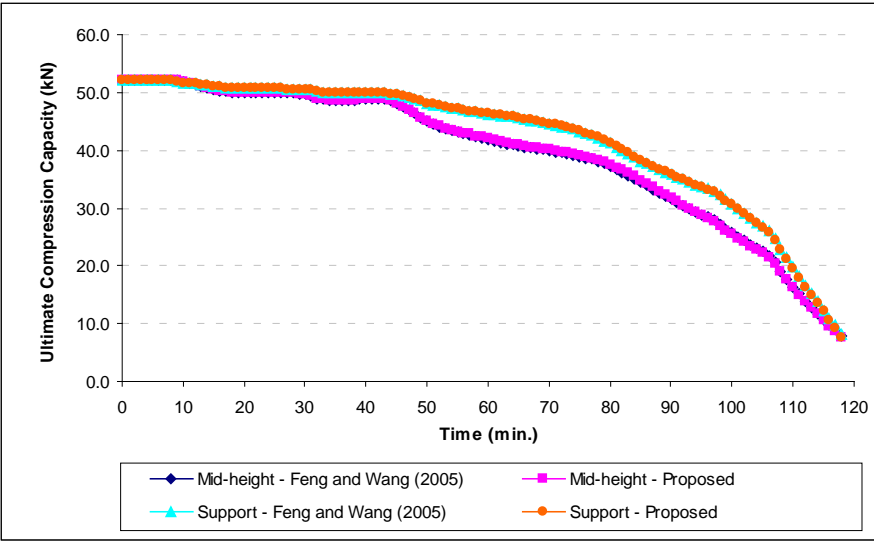

(b) Test 1*

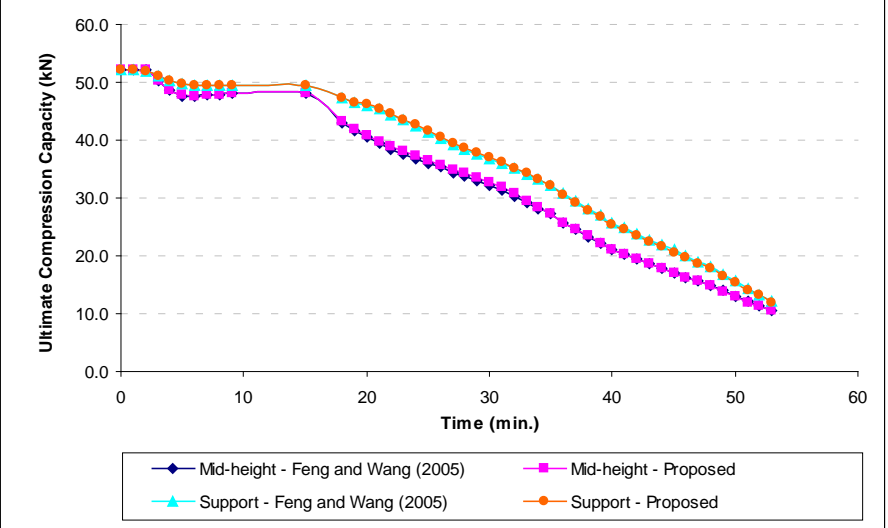

(c) Test 2*

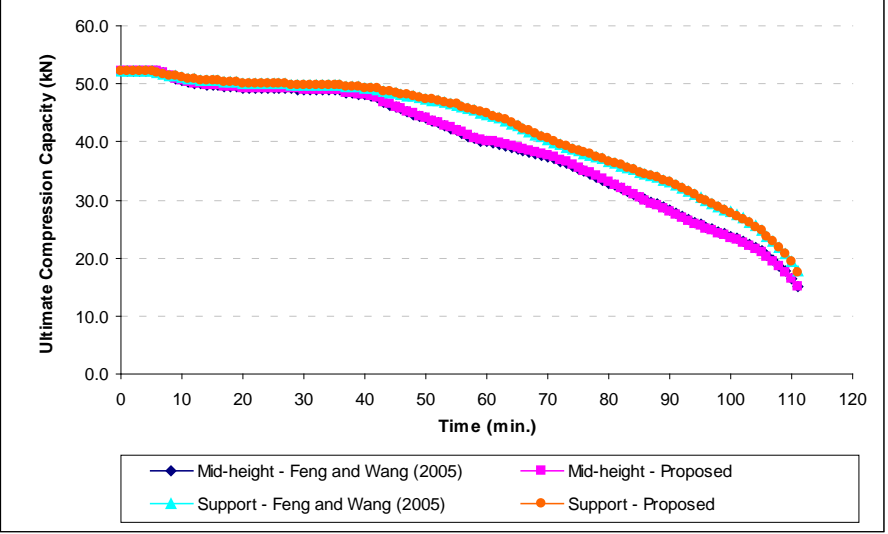

(d) Test 4*

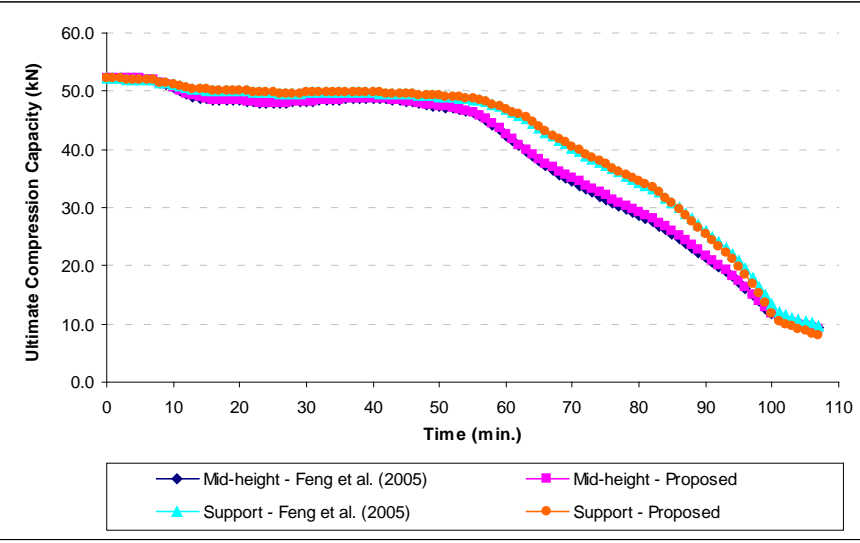

Figure 15: Variation of Ultimate Compression Capacity with Time 


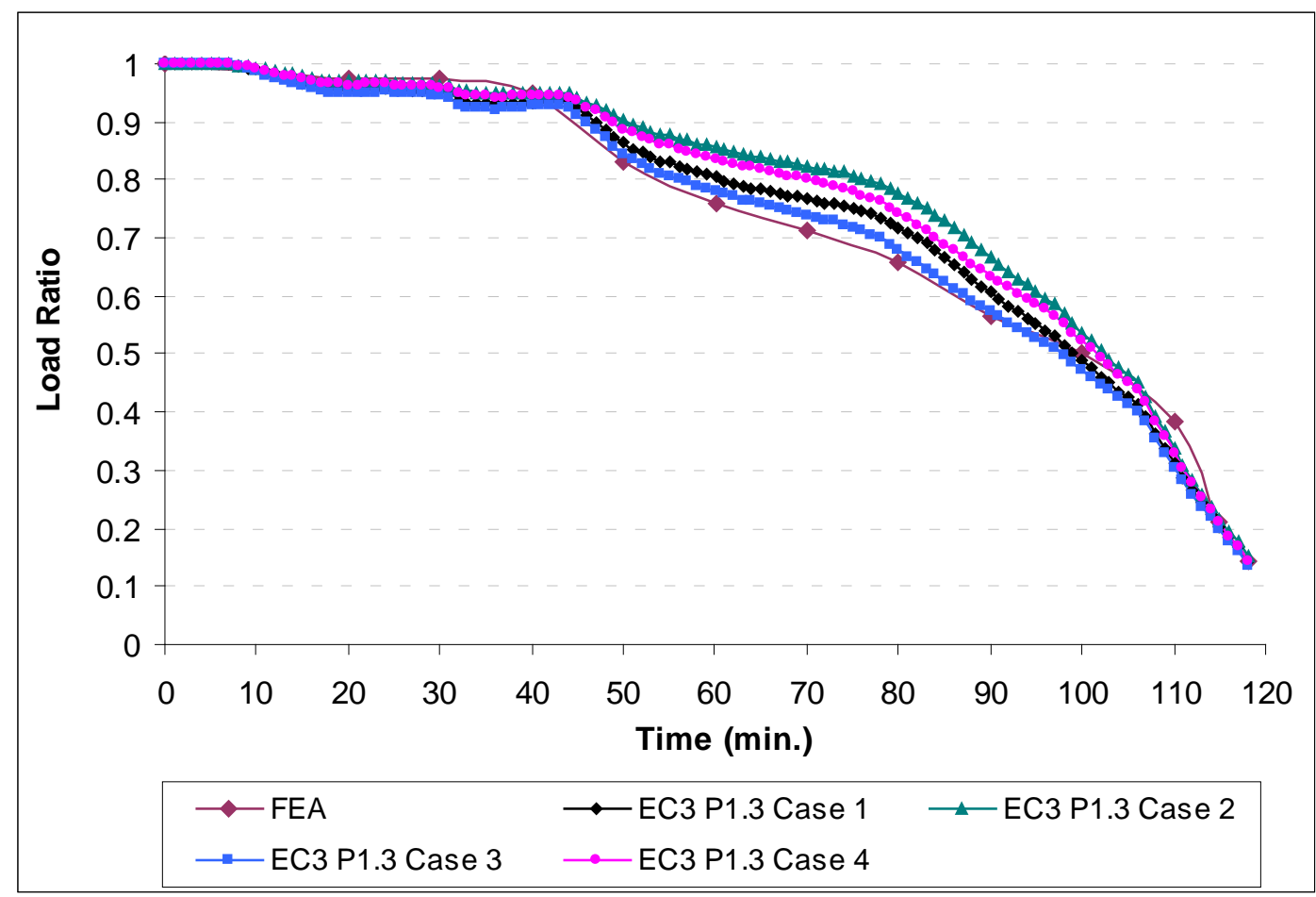

Figure 16: Variation of Load Ratio with Time for Test 4* 


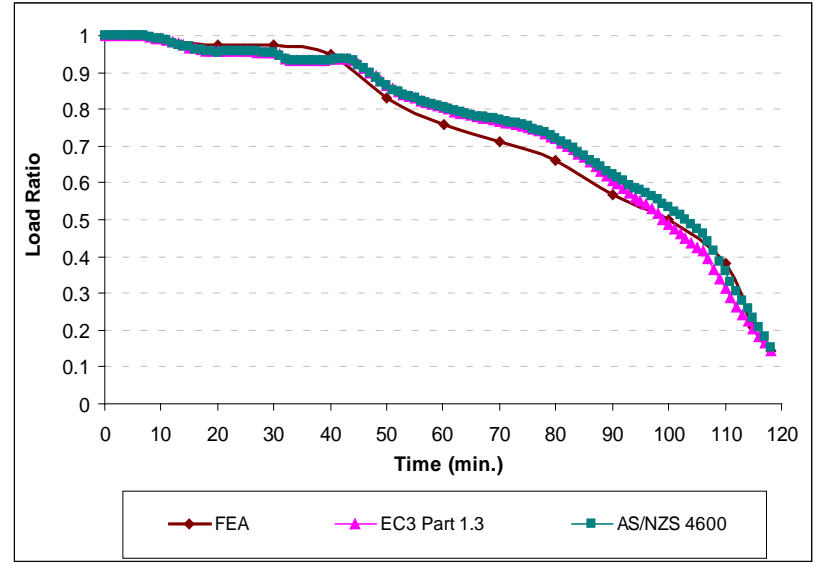

(a) Test 1

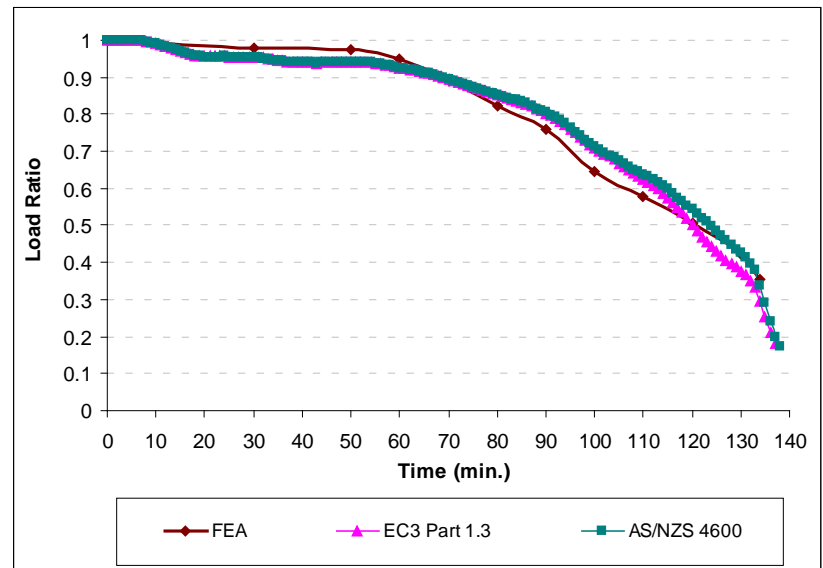

(c) Test 3

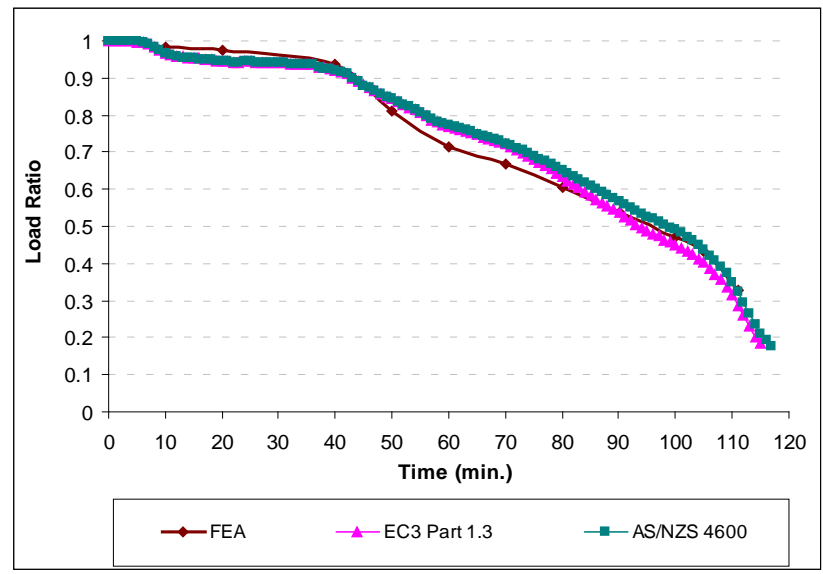

(e) Test 2*

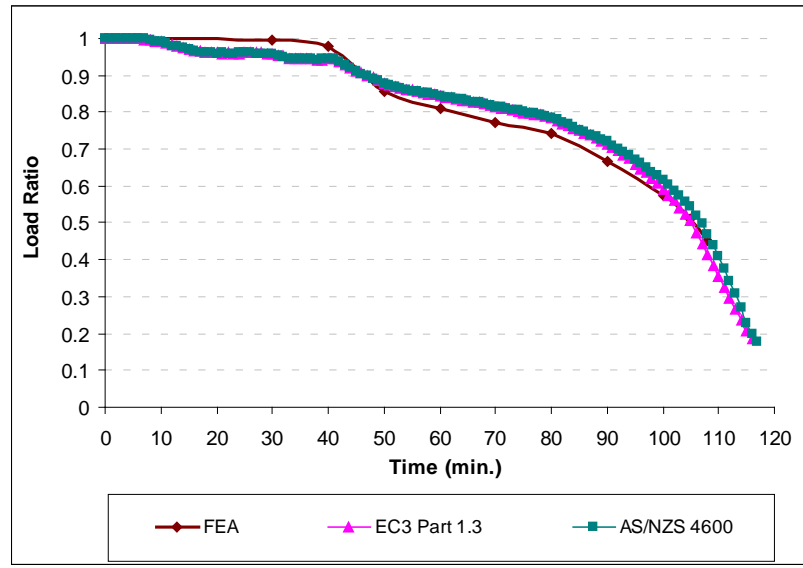

(b) Test 2

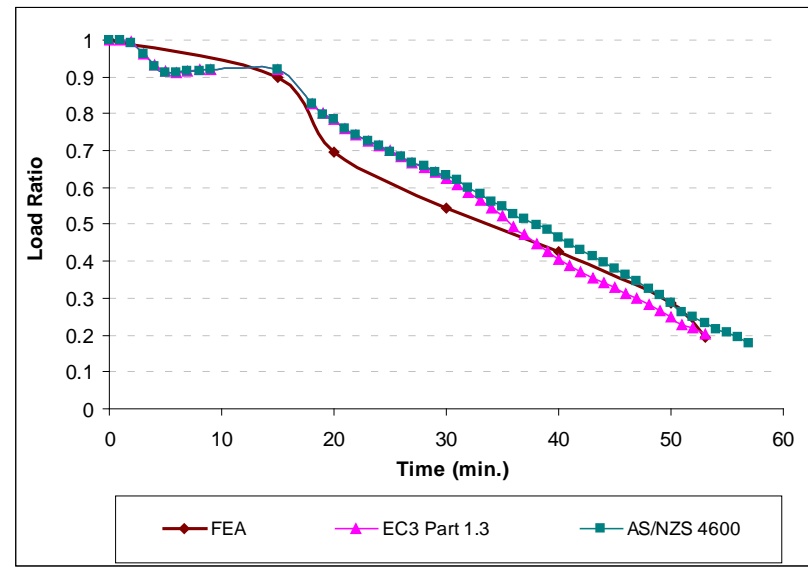

(d) Test $1^{*}$

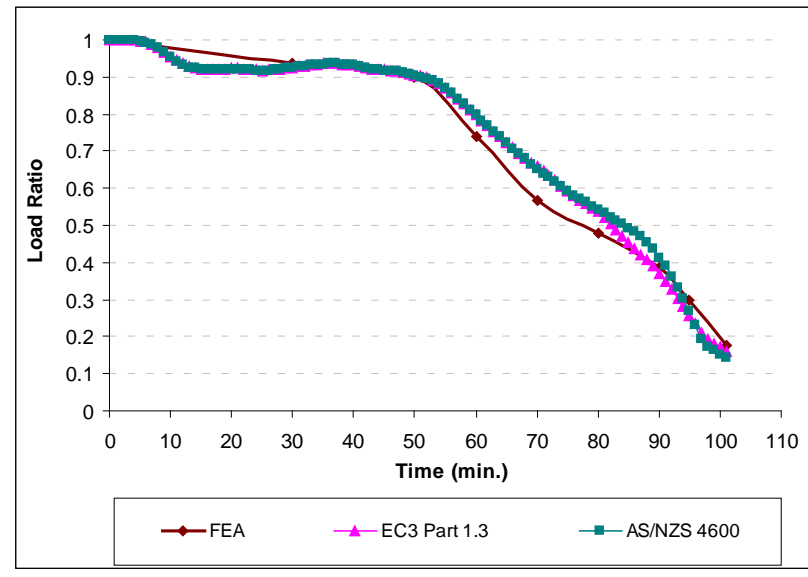

(f) Test 3*

Figure 17: Load Ratio versus Time Curves from FEA and Proposed Fire Design Rules 


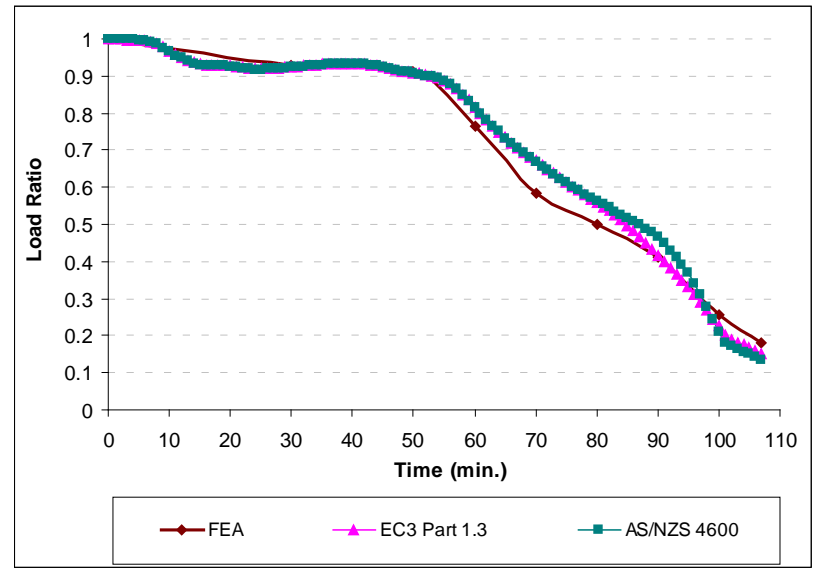

(g) Test 4*

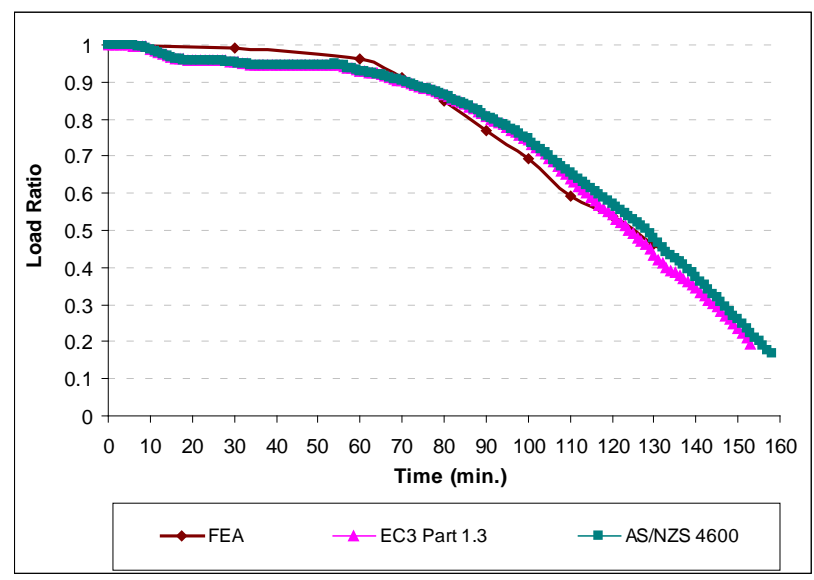

(i) Test 6*

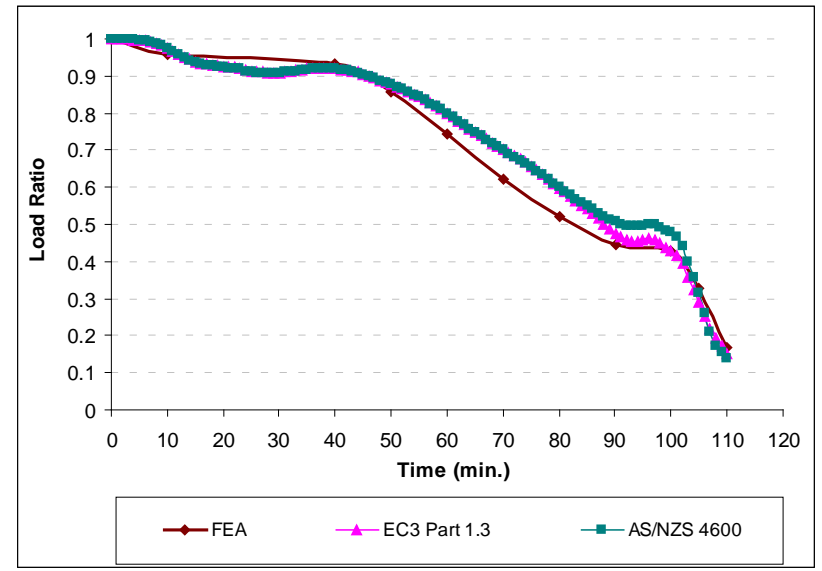

(h) Test 5*

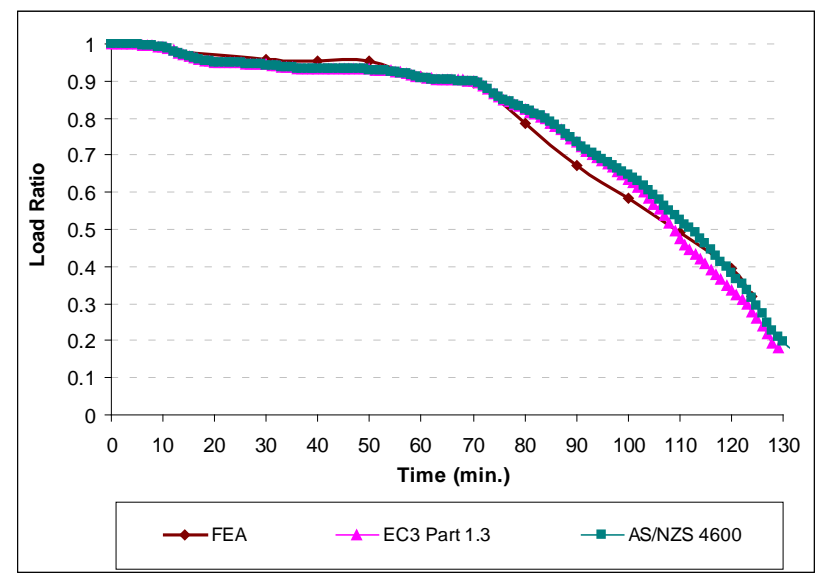

(j) Test 7*

Figure 17: Load Ratio versus Time Curves from FEA and Proposed Fire Design

\section{Rules}


(a) $1 \times 1$

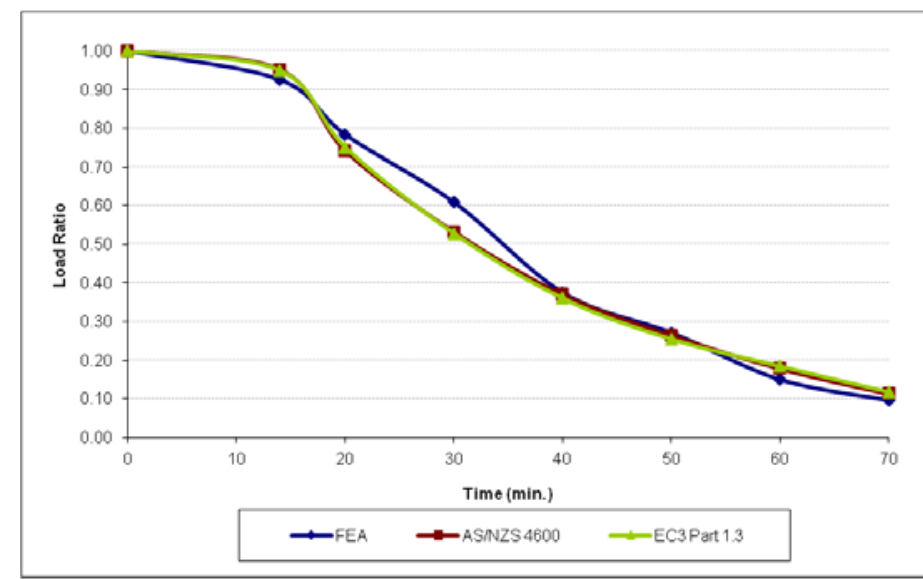

(b) $2 \times 2$

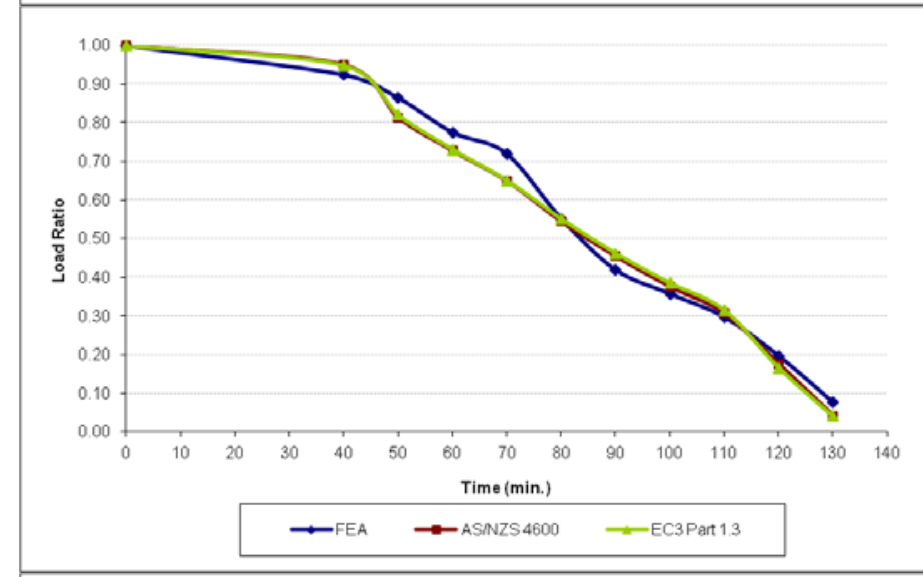

(c) CI-GF

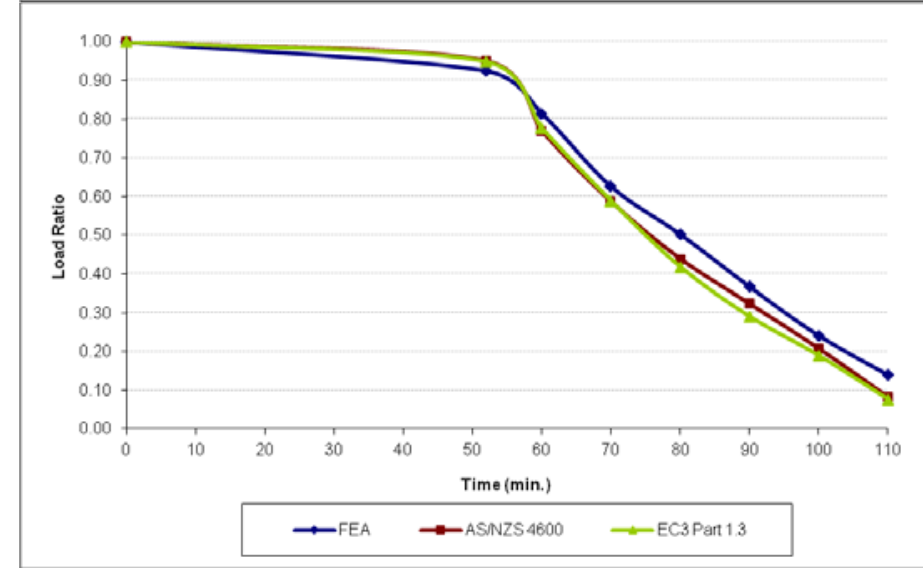

(d) CI-RF

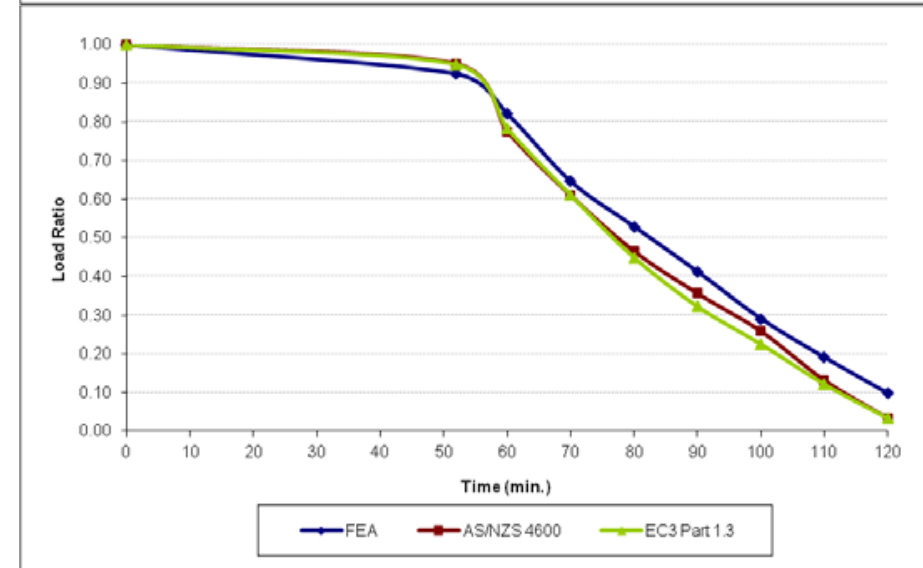

Figure 18: Comparison of Proposed Fire Design Rules with FEA Results for 1.15 mm G250 Steel Studs Lined on Both Sides by Two Layers of Plasterboard 
(e) CI-CF

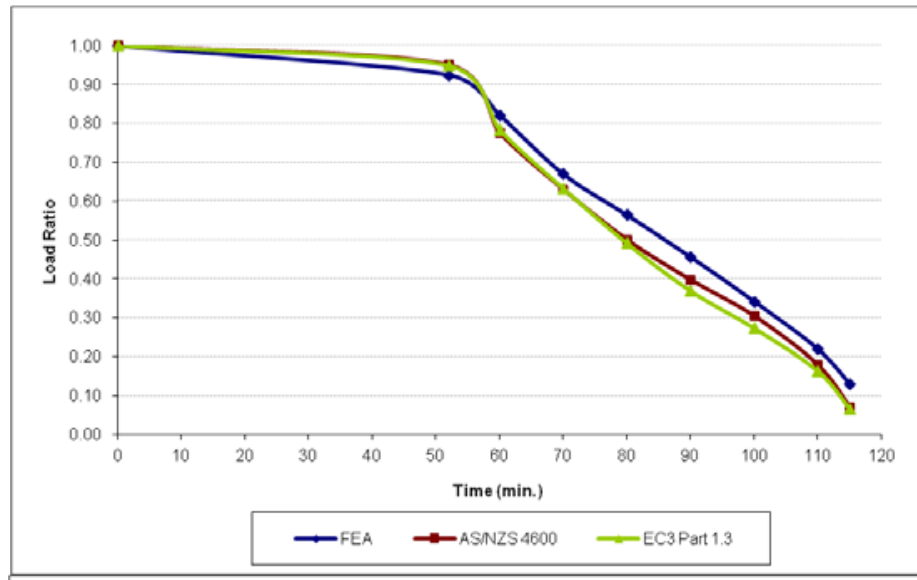

(f) CP-GF

(g) CP-RF
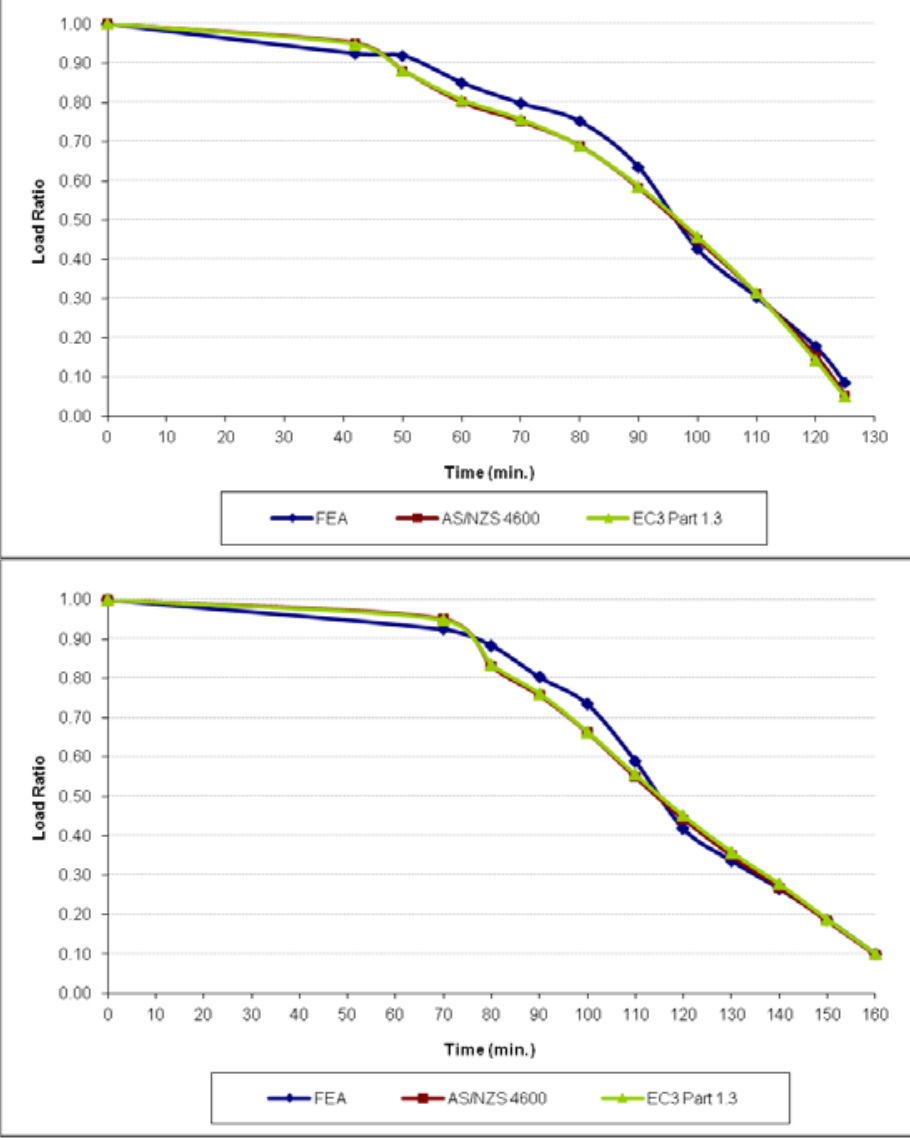

(h) $\mathrm{CP}-\mathrm{CF}$

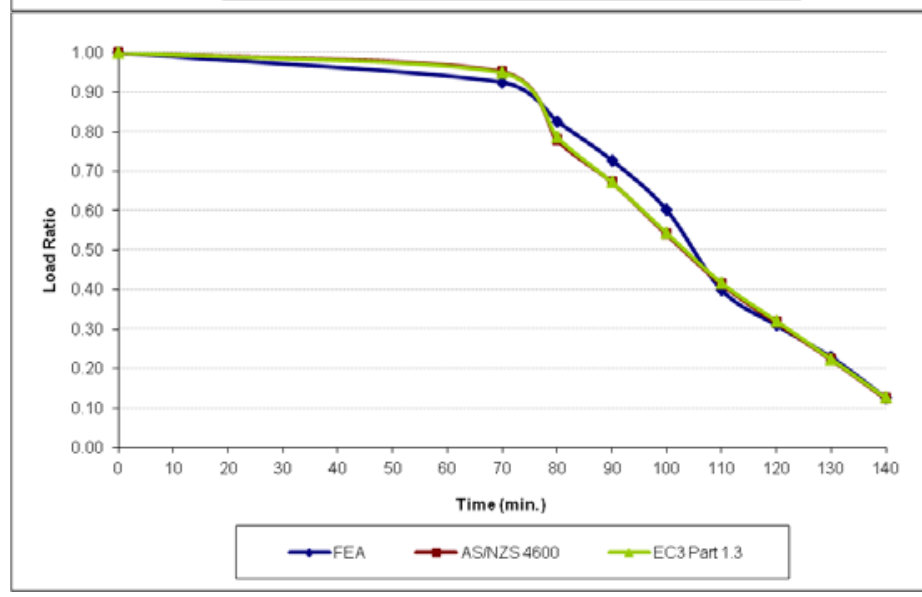

Figure 18: Comparison of Proposed Fire Design Rules with FEA Results for 1.15 mm G250 Steel Studs Lined on Both Sides by Two Layers of Plasterboard 
(a) $1 \times 1$

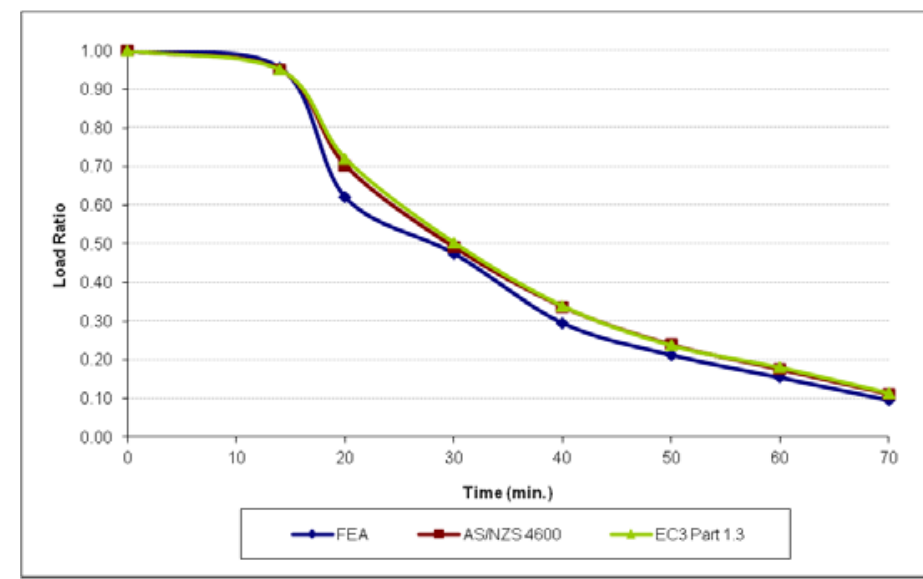

(b) $2 \times 2$

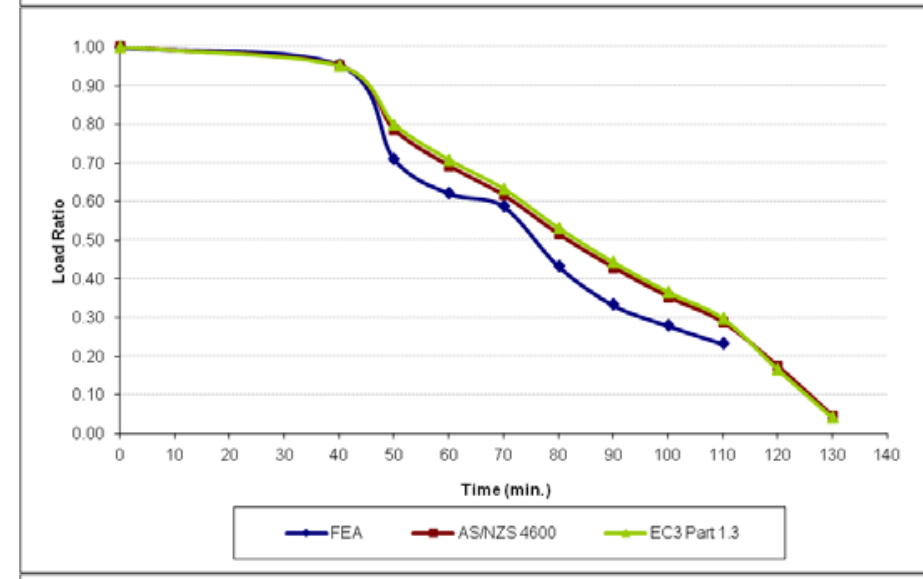

(c) CI-GF

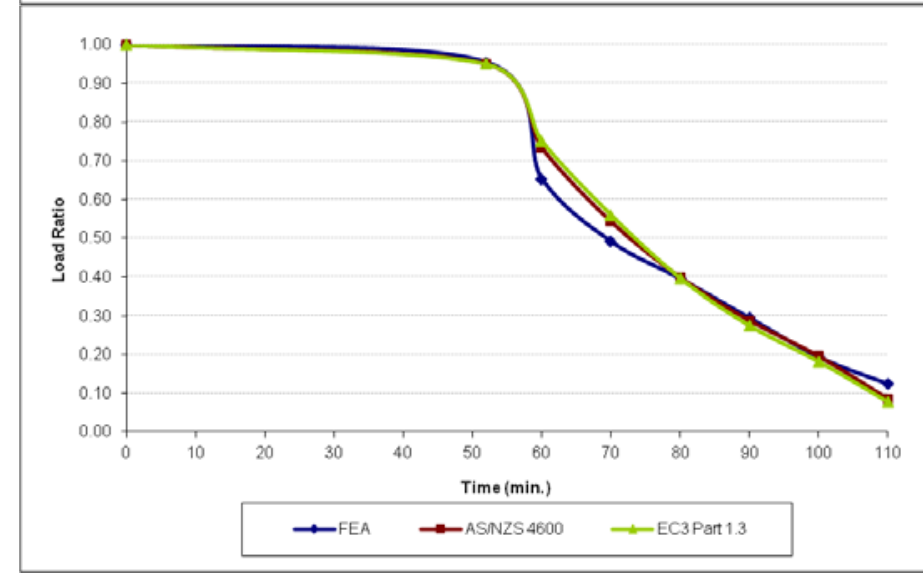

(d) CI-RF

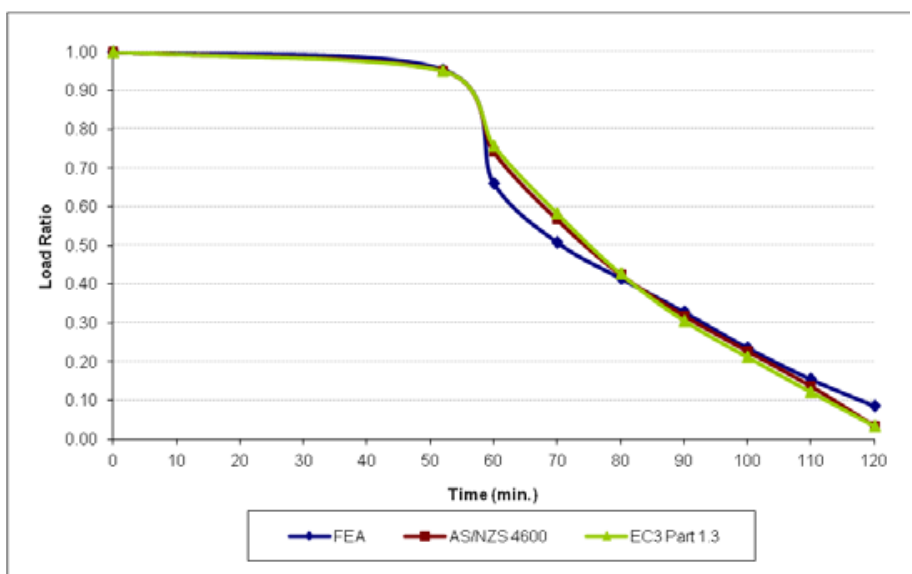

Figure 19: Comparison of Proposed Fire Design Rules with FEA Results for 1.95 mm G250 Steel Studs Lined on Both Sides by Two Layers of Plasterboard 
(e) CI-CF

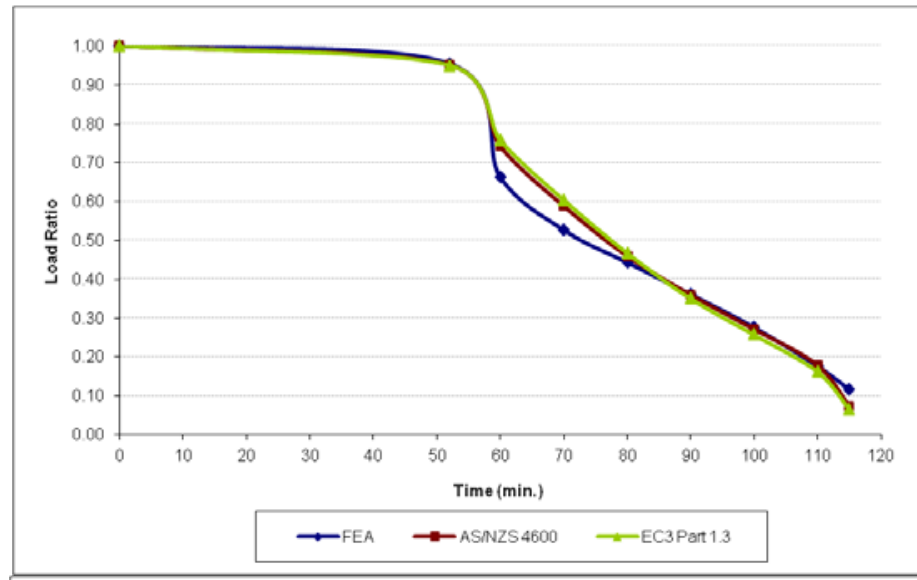

(f) CP-GF

(g) CP-RF
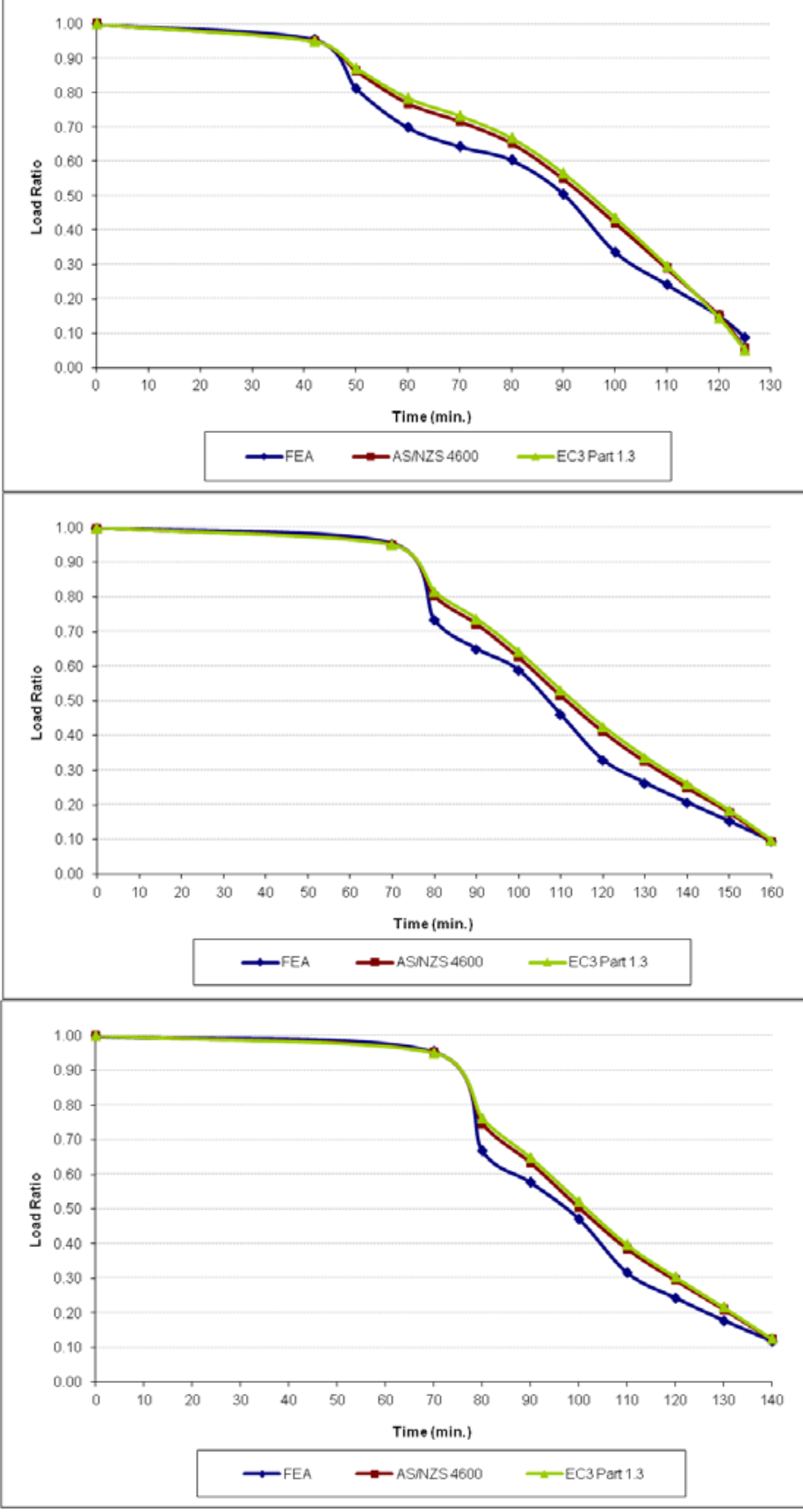

Figure 19: Comparison of Proposed Fire Design Rules with FEA Results for 1.95 mm G250 Steel Studs Lined on Both Sides by Two Layers of Plasterboard 